\title{
The Democratic Class Struggle in Postwar Societies: Class Voting in Twenty Countries, 1945-1990
}

\author{
Paul Nieuwbeerta \\ Utrecht University
}

\begin{abstract}
Studies on the relation between class and voting behaviour traditionally use measures of absolute class voting (Alford indices), and apply simple class schemes (a manual/non-manual class dichotomy). Almost all these studies showed that levels of class voting differed between countries and that declines in levels of class voting occurred in most countries in the postwar period. However, recently, scholars have argued that using measures of relative class voting (e.g. log-odds-ratios) and more detailed class schemes (e.g. the EGP class scheme) might yield different conclusions. In this article the tenability of this claim is tested analysing comparable data from twenty Western industrial democracies in the period 1945-90. The main finding is that the different measurement procedures do not lead to essentially different conclusions. Using various procedures, a similar ranking of the countries with respect to their levels of class voting was obtained: the Scandinavian countries and Britain having the highest levels of class voting, and the United States and Canada the lowest. Furthermore, on using the various procedures, declines in levels of relative class voting were indicated in the same countries (particularly the Scandinavian countries, Germany and Britain), while no evidence of substantial declines was found in others (Canada, Ireland, Luxembourg, Switzerland and The Netherlands).
\end{abstract}

Paul Nieuwbeerta, Department of Sociology, University of Utrecht, Heidelberglaan 1, 3584 CS Utrecht, The Netherlands

(C) Scandinavian Sociological Association 1996

\section{Introduction}

A common feature of elections in western societies - that are commonly regarded as the platform of 'the democratic class struggle' (Anderson \& Davidson 1943; Lipset 1960; Korpi 1983; Przeworski \& Spraque 1986) - is that people from the lower classes are more likely to vote for left-wing parties 
than are people from other classes. The purpose of this article is to describe the strength of the relationship between class and voting behaviour in Western industrialized countries in the postwar period.

From the start of research on stratification and politics, studies have been concerned with the relationship between social class and voting behaviour. The first studies on this topic were characterized by the use of a dichotomous manual/non-manual class scheme. In addition the focus was on the absolute levels of class voting, measured by the so-called Alford index. These studies showed that in all Western democratic countries, members of the manual classes were more likely to vote for left-wing political parties than were members of non-manual classes. They also revealed that the strength of the link between class and voting behaviour was different from country to country, and that declines in class voting occurred in most countries in the postwar period (Kemp 1978; Andeweg 1982; Korpi 1983:35; Lipset 1983; Lane \& Ersson 1991:94; Franklin 1985b; Dalton 1988; Inglehart 1990; Clark et al. 1993:312).

Nevertheless, scholars from later generations argue that, although differences and trends in class voting were found in earlier studies, it is not clear whether these differences and trends would be found when examining levels of class voting in a more appropriate way (Korpi 1983; Heath et al. 1985; Hout et al. 1993; Goldthorpe 1994). First, they claim that the traditionally used measure of class voting, i.e. the Alford index, is sensitive to variation in the general popularity of political parties. Therefore, they argue, one should focus on levels of relative class voting instead of absolute class voting, and measure this by means of odds-ratios, or log-odds-ratios instead of Alford indices. Second, they argue that earlier studies used class schemes too crude to take relevant developments in the class structure in these countries into account.

The critique on the approach of traditional class voting studies has led to strong debates in the literature between scholars advocating both standpoints (see, e.g., Clark \& Lipset 1991; Crewe, 1986; Heath et al. 1985, 1991; Hout et al. 1993). In these debates, however, these scholars could refer to only a very limited number of studies using measures of relative class voting and detailed class schemes and examining levels of class voting in many countries simultaneously and over a long period. In fact, the only studies done (Heath et al. 1995; Hout et al. 1995; Ringdal \& Hines 1995) focused on trends in single countries, i.e. Britain, France, Norway and the United States.

It is against this background that in this article we raise the following descriptive research questions: To what extent did levels of relative class voting differ across democratic industrialized countries in the postwar period?, and: To what extent was there a decline in levels of relative class voting in these countries over that period? In order to answer these questions, we follow a long line of studies that have examined this relationship, but we endeavour to improve on these first by analysing data from twenty countries over the period 1945-90, second by employing both the traditionally used manual/non-manual class scheme and a detailed class scheme (the EGP class scheme), and third by using measures of both absolute and relative class voting. A comparison of the results for (absolute) manual/non-manual class 


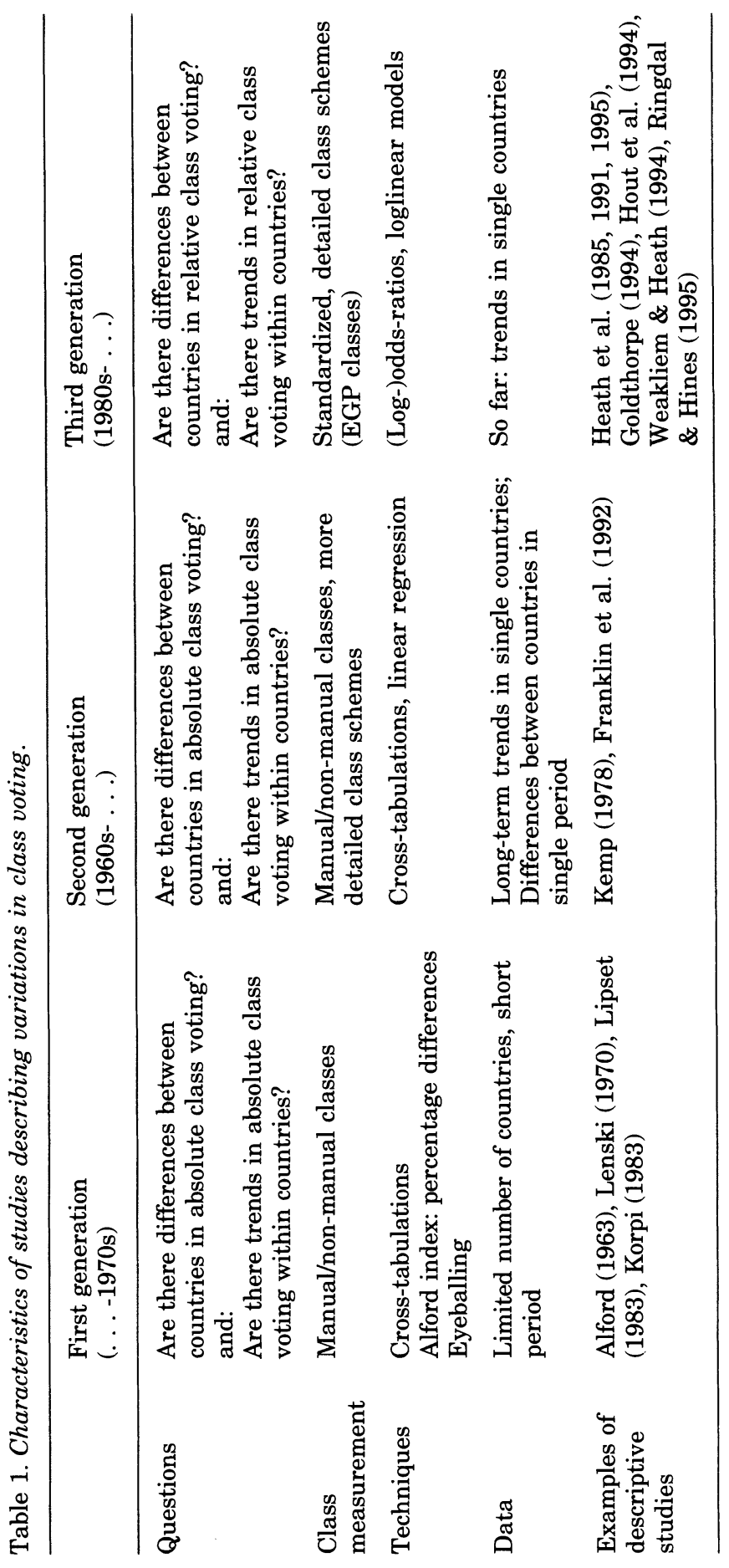


voting and relative EGP class voting will give an indication to what extent conclusions from traditional studies were flawed.

\section{Earlier studies on class voting}

The history of research on the relationship between social stratification and voting behaviour can be divided into three generations (see Table 1). These generations are comparable to those in which the history of comparative intergenerational social stratification and mobility research is commonly divided (Featherman et al. 1974; Kurz \& Muller 1987; Ganzeboom et al. 1991; Ultee 1993). The three generations can be distinguished by the following criteria: (a) the articulation of research problems, (b) the content of major hypotheses, (c) measurement procedures, (d) data collection, and (e) methods of data analysis. We are aware that the three generations are not truly separated in time. Nevertheless, it is still informative to review the history of this research area by contemplating these generations in a developmental perspective. Doing this, the progress in measurement procedures and methods of data analysis might seem somewhat more influential than progress on research problems and hypotheses. This view, however, is mistaken. The developments of new measurement procedures and methods of analysis have indeed offered opportunities to answer old substantive questions more adequately and to address new, more precise questions (see also: Ultee 1993; Nieuwbeerta 1995).

\section{First generation}

Studies on the relationship between social stratification and politics have been carried out since long before World War II. However, most of these classic studies were based on impressionistic data (Sombart 1976 [1906]; Sorokin 1959 [1927]) or on aggregated ecological data (Tingsten 1937; Siegfried 1913). The first research contributions on stratification and politics based on national representative surveys of the electorate appeared in the United States only after 1950 (e.g. Campbell et al. 1960). These were followed by studies based on surveys of countries in Western Europe and other Western industrialized countries (Den Uyl 1951; Valen \& Katz 1967; Alford 1963; MacRae 1967; Butler \& Stokes 1974). The first generation of research on stratification and politics began by asking whether a relationship existed between an individual's social and economic position and his voting behaviour. Consequently, many monographs and articles published in the $1950 \mathrm{~s}$ and $1960 \mathrm{~s}$ on this topic include tables that cross-classify income, education, or occupation against voting behaviour (Svalastoga 1979; Lipset \& Zetterberg 1956). For all countries examined, these studies showed that people in the lower social strata are more likely to vote for left-wing political parties than people in higher classes.

Since studies were conducted in various countries, it became possible to make cross-country comparisons of the strengths of links between people's class position and their voting behaviour. However, making such comparisons of separate studies of different countries was often problematic. For example, in some studies personal income was used as a measure of people's social and economic position, whereas in others education or occupation was 
used. Moreover, even when researchers used the same type of measure, classifications often varied from the very detailed to the very crude. Thus, Lipset (1960) - in one of the first studies to display class voting tables integrating data from different countries (Britain, France and Italy) - did not present a single standardized measure of levels of class voting. Similarly, the international comparative studies by Rose \& Urwin (1969) and by Rose (1974) brought together tables on the influence of people's social position in many countries, but without a standardized measure of class voting.

Alford $(1963,1967)$ made the first major attempt at a truly comparable cross-national analysis using standardized measures. He presented data from four Anglo-American countries (Australia, Britain, Canada, and the United States), while using a measure of people's social and economic position that was comparable cross-nationally and over time. In order to achieve such a measure he collapsed various occupations or classes into a dichotomous manual/non-manual class distinction. This manual/non-manual class distinction became the standard measurement procedure in crossnational or trend studies of the first generation. All studies showed that people from the manual class were more likely to vote for left-wing parties than were people from the non-manual class. There seem to have been two reasons why class, and not income or education became the prime tool for comparative and over-time research. The first is that a person's class is a better discriminator of his political interests and his voting behaviour than any of the other measures. The second reason is that information about respondent's class is more often comparable than information on respondent's income or education in the available survey data.

Alford also proposed a standardized measure of the strength of the relationship between class and voting behaviour in a country for crossnational and over-time analyses. Although various alternative measures for the level of class voting in a country were suggested (see e.g., Campbell et al. 1960), the index proposed by Alford (1962) became the standard in studies on this topic. The so-called 'Alford index' is obtained by taking for a two by two table cross-classifying class (manual/non-manual) by party voted for (leftwing/right-wing), the difference between the percentage of manual workers that voted for left-wing political parties on the one hand and the percentage of non-manual workers that voted for these parties on the other.

After Alford's study, it took some years before more cross-national studies on the relationship between class and voting behaviour appeared that use standardized measures of the strength of that relationship. Indeed, only since the 1970 s have researchers presented comparable data, class schemes, and measures on class voting on a dozen of countries (Books \& Reynolds 1975). Lenski (1970:362) and Lijphart (1971:162) presented data for a considerable number of Western industrialized countries surveyed around the 1960s. A decade later, Korpi (1983:35) presented data showing differences across eighteen countries in the 1970s. Recently, Lane \& Ersson (1991:94) corroborated this finding for sixteen countries during the 1980s. All these first generation studies showed that substantial differences between countries in their levels of class voting existed in the postwar period, with the Scandinavian countries and Britain having the highest levels of class voting, and the United States and Canada the lowest. 
In addition to cross-national analyses, first generation studies also examined trends in the levels of class voting within countries. Alford's (1963:103) pioneering study examined trends in class voting in four AngloAmerican democracies in the period between 1936 and 1962. Later this study was updated and extended to other countries and other periods (Abramson et al. 1990; Franklin 1985a, 1985b; Kemp 1978; Baker et al. 1981; Stephens 1981). For example, Andeweg (1982) has analysed trends in the strength of the relationship between class and vote for The Netherlands, Abramson and his colleagues (1990) for the United States, and Listhaug (1989) for Norway. Furthermore, some have examined trends in the levels of class voting in several countries simultaneously. Lipset (1983:505) has presented evidence of a downward trend in Britain, Germany, and the United States between 1945 and 1980 . A continuing decline has been supported by further analyses of data from the early 1980s (Inglehart 1990:260; Clark et al. 1993:313). In addition, Sainsbury $(1987,1990)$ has shown a decline in class voting in the Scandinavian countries, while Lane \& Ersson (1991:94), comparing the 1950/ 60 s with the $1970 / 80 \mathrm{~s}$, have found less class voting in the later period for nine Western industrialized nations and stronger class voting in only two countries (France and Italy). In general, these studies provided evidence of a downward trend in class voting in Western democratic countries.

\section{Second generation}

The second generation of research on social stratification and politics made only a small contribution to research on the relationship between class and voting behaviour. Instead, political science research during this period was characterized by a focus on 'social-psychological' explanations of individual voting behaviour, while 'sociological' explanations received less attention. The aim was to increase the amount of variance in voting behaviour explained by adding variables to the equation, rather than to explain the strength of the relationship between class and voting behaviour. Furthermore, in social stratification research generally, questions about the political consequences of stratification were given low priority. Nevertheless, where they were studied, the analyses were more sophisticated than those of the first generation, and linear regression or path models replaced simple analyses of cross-tabulations.

The new regression techniques offered a better possibility of analysing the effects of class, while controlling for the effects of other factors, than tabular analyses. Most of the relevant second generation studies showed that class - even when controlling for other factors like religion and education had a substantial effect on voting behaviour, in the sense that the lower classes wee more apt to vote for a left-wing political party than were the higher classes (McAllister \& Kelley 1982; Franklin 1985a, 1985b). Scholars of this generation also used path models to get a better insight into the influence of people's origin class and their current class on their voting behaviour (Knocke 1973; Kelley \& McAllister 1985).

However, only a small number of studies in the second generation dealt with describing differences between countries or trends within countries in levels of class voting (Kemp 1978). One exception, published in 1992, was the study by Franklin and his colleagues on electoral change in twenty countries. 
In this study linear regression models on voting behaviour (left/right) were estimated for all countries, including as explanatory variables social characteristics such as class (manual/non-manual), religion and value orientations. However, because the operationalization of variables was not always comparable between countries, and since for the different countries different variables were included in the analyses, no conclusions about crosscountry differences in the effects of class on voting behaviour could be drawn (Nieuwbeerta \& Ultee 1993). Furthermore, because for each of the countries only three data sets were analysed (one for the 1960s, one for the 1970s, and one for the 1980s), conclusions on trends could only be drawn tentatively.

\section{Third generation}

The study of voting behaviour in Britain by Heath and his colleagues in 1985 can be regarded as the first major contribution to the third generation of research on stratification and politics. Researchers of this generation recognized the applicability of measurement procedures and analysis techniques common in mobility research, to questions on the relationship between class and voting behaviour. Thus, they began to employ these tools that among others included a detailed cross-nationally comparable class scheme and loglinear models especially equipped for analysing (log-)oddsratios - in this area. As a result, these later studies are able to deal with new or more specific questions, and generate better answers to old research questions.

To begin with, scholars of the third generation argued that measures of the strength of a relationship between two categorical variables - like class and voting behaviour - should be independent of variation in the distributions of these variables. Since variation in Alford indices might be due to their sensitivity to variation in the general popularity of political parties, third generation researchers proposed a measure of class voting unaffected by these changes (Heath et al. 1985). Specifically, they argued that the focus should not be on absolute levels of class voting, but on the socalled 'relative' class voting, measured by odds-ratios or by log-odds-ratios (Heath et al. 1985; Thomsen 1987). These measures have in this context an advantage over other measures - like the Alford index - in that they measure the strength of the relationship between class and vote, independent of the general popularity of political parties.

In addition, scholars of the third generation have claimed that, with respect to measurement procedures, a more detailed internationally comparable class scheme was preferable to the manual/non-manual class dichotomy. They have argued that the manual/non-manual distinction hides variations in the compositions of the manual and non-manual classes, and therefore obscures results when describing the relationship between class and voting behaviour. To overcome this problem, they introduced a class scheme - originally used in mobility research - that is comparable crossnationally and over time. This scheme was developed by Erikson, Goldthorpe \& Portocarrero (1979), and later elaborated by Erikson \& Goldthorpe (1992). Since then this so-called 'EGP scheme' has frequently been used, first in mobility studies, and subsequently in studies on the relationship between class and voting behaviour (e.g. Evans et al. 1991; De Graaf et al. 1995). The 
advantage of this categorical class scheme over prestige or status measures of people's social position in a society when predicting peoples voting behaviour is that using the latter measures the voting behaviour of farmers and other self-employed cannot readily be predicted.

Studies of the third generation of research on stratification and politics, borrowed not only measurement conventions from mobility research, but also techniques of data analysis. In mobility research, specific log-linear models were developed to describe patterns of association in a cross-classifying table, and to test whether differences exist between tables in the strength of the associations (Hauser 1978; Erikson \& Goldthorpe 1992). These models and the odds-ratios on which they are based were introduced into research on the class/vote relationship by Heath et al. (1985). The application of such techniques is a central characteristic of studies of the third generation.

As already suggested, the use of detailed standardized class schemes and techniques built on log-odds-ratios to describe levels of class voting of countries is a quite recent innovation. Consequently, only a limited number of empirical studies using these innovations have been done. The first studies were carried out by Heath et al. (1985, 1991), Weakliem (1989), and Evans et al. (1991), describing trends in class voting in Britain. The analyses in these studies investigated linear trends in the log-odds-ratios. In subsequent analyses proportional trends were examined, by using the so-called 'uniform difference' models (Xie 1992; Erikson \& Goldthorpe 1992). Hout et al. (1995) used these models to do analyses for the United States, Goldthorpe (1994) and Heath et al. (1995) for Britain. Furthermore, Weakliem \& Heath (1994) applied these log-linear models to an investigation of Britain, France and the United States, and Ringdal \& Hines (1995) to a study of class voting in Norway. However, in general this third generation is still in its infancy and has yet to live up to its expectations. By answering the research question in this article, we aim to contribute to these developments.

\section{Data and operationalizations}

\section{Data}

To address the research questions of this study, data from twenty countries over the period 1945-90 are analysed. These twenty countries can be considered as having been basically democratic over a substantial period of time (Lijphart 1984:37). Our set of twenty countries included all countries in Western Europe (except Iceland), two countries from the continent of North America (Canada and the United States), and Australia.

In the analyses two kinds of data were employed for the twenty countries under investigation in the postwar period. The first kind of data, the aggregated country data, includes information about the levels of class voting for each of the twenty Western industrialized countries in each year since the end of World War II. These data were obtained from two sources: tables published in various articles and books, and tables calculated using data from several national representative surveys available on tapes (i.e. our individual data set). In total for all twenty countries, 324 tables crossclassifying class (manual/non-manual) by party voted for (left-wing/right- 
wing) were found. In Appendix A the sources of these class voting tables are listed.

The second kind of data, the individual level data, were used from national representative surveys of these countries. These data pertain to 75,783 male respondents aged eighteen years or older from 113 surveys held in sixteen out of the twenty countries and covering the period 1956-90. For Greece, Luxembourg, Portugal, and Spain no useful individual level datafiles were found. More detailed information about these files is given in Appendix B.

\section{Voting behaviour}

To measure levels of class-based voting, it would be preferable to have data on the actual voting behaviour of respondents during specific elections in the surveys. However, because voting is confidential in democratic countries, we have to rely on indirect measures of voting behaviour in the surveys. In some surveys respondents were asked to name the political party they would vote for if there were a national election tomorrow. In other surveys respondents were asked to name the party they voted for at the most recent national election. In yet others respondents were asked which political party they preferred or identified with. ${ }^{1}$

In order to produce a classification of parties voted for that would allow cross-country comparison, we followed Bartolini \& Mair (1990) and Franklin and his colleagues (1992), and dichotomized the political parties into leftwing on one side and right-wing on the other. This distinction can be seen as the most relevant distinction between political parties, when investigating class-based voting. To oversimplify, left-wing parties prefer a change in the direction of greater social equality, i.e. their policies are in favour of the manual classes, whereas right-wing parties are against such changes (Lipset 1960), i.e. their policies are in the interests of non-manual classes. In deciding whether a specific party should be included in the left-wing block, we followed the criteria given by Bartolini \& Mair (1990:42-43) and included all parties which were members of the Socialist International or the Communist Third International. Since according to these criteria hardly any left-wing voters would exist in the United States, for that country an exception to the criteria was made, and the Democratic Party was defined as a left-wing party. In Appendix $\mathrm{C}$ we present a list of the political parties which were classified as left-wing in this study.

\section{Social class}

A manual versus non-manual class distinction is traditionally used in research on the relationship between social class and voting behaviour. In this article we follow this tradition. However, in line with the arguments of third generation scholars we also use a more detailed class scheme, i.e. the seven class version of a class scheme originally introduced by Goldthorpe for the Oxford Mobility Inquiry (Goldthorpe et al. 1978), and later elaborated by Erikson, Goldthorpe \& Portocarrero (1979), and Erikson \& Goldthorpe (1992:38-39). The seven class version of this - for brevity's sake called - EGP class scheme distinguishes between the class categories given in Table 2 . We have chosen this EGP class scheme, since it has been useful in comparative 
studies of intergenerational class mobility (Ganzeboom et al. 1989; Erikson \& Goldthorpe 1992), and in studies examining the relationship between social class and voting behaviour (Heath et al. 1985; Evans et al. 1991) as well as in studies of the effects of class mobility on voting behaviour (De Graaf et al. 1995; Nieuwbeerta 1995, 1996).

In order to obtain a comparable operationalization of class in all countries and years, the respondents were coded into the EGP classes on the basis of data on their occupation, self-employment and supervisory status in two steps. First, the original occupation codes were recoded into the International Standard Classification of Occupation (ISCO) codes (ILO 1969). Second, these ISCO codes were translated into EGP scores through the Ganzeboom et al. (1989) recoding scheme.

\section{Manual/non-manual class voting}

The level of class voting in a country at a certain point in time can be operationalized in various ways. Traditionally, as we already discussed, the Alford index has been used (Alford 1962, 1963). The index is obtained by taking, for a two by two table cross-classifying class (manual/non-manual) and voting behaviour (left-wing/right-wing), the difference between the percentage of manual workers that voted for left-wing political parties on the one hand and the percentage of non-manual workers that voted for these parties on the other hand.

Recently, scholars of the third generation of research on stratification and politics have proposed the log-odds-ratio as a measure of the strength of the class/vote relationship (Heath et al. 1985; Thomsen 1987; Hout et al. 1995; Manza et al. 1995). The log-odds-ratio is the natural logarithm of the

Table 2. Social class scheme: EGP categories.

\begin{tabular}{ll}
\hline Title & Description \\
\hline $\begin{array}{l}\text { Non-manual classes } \\
\text { Service class }\end{array}$ & $\begin{array}{l}\text { Large proprietors; professionals, administrators and managers; } \\
\text { higher-grade technicians; supervisors of non-manual workers. }\end{array}$ \\
$\begin{array}{l}\text { Routine non- } \\
\text { manual class }\end{array}$ & $\begin{array}{l}\text { Routine non-manual employees in administration and } \\
\text { commerce; sales personnel; other rank-and-file service workers. }\end{array}$ \\
$\begin{array}{l}\text { Petty bourgeoisie } \\
\text { Farmers }\end{array}$ & $\begin{array}{l}\text { Small proprietors and artisans, with and without employees. } \\
\text { Farmers, smallholders and other self-employed workers in } \\
\text { primary production. }\end{array}$ \\
$\begin{array}{l}\text { Manual classes: } \\
\text { Skilled workers }\end{array}$ & $\begin{array}{l}\text { Lower-grade technicians; supervisors of manual workers; skilled } \\
\text { manual workers. }\end{array}$ \\
$\begin{array}{l}\text { Non-skilled } \\
\text { workers }\end{array}$ & Semi- and unskilled, non-agricultural manual workers. \\
$\begin{array}{l}\text { Agricultural } \\
\text { labourers }\end{array}$ & Agricultural and other workers in primary production.
\end{tabular}


odds-ratio, where the odds-ratio is the odds for manual workers of voting leftwing rather than right-wing divided by the odds for non-manual workers of doing the same. ${ }^{2}$ This log-odds-ratio can also be regarded as the log-odds for manual workers of voting for a left-wing political party rather than a rightwing party minus the log-odds for non-manual workers of voting in this way. If voting behaviour is not dependent on class, the log-odds-ratio has the value of zero. As a tribute to the scholar who was one of the first to apply the logodds-ratio in research on stratification and politics, we call this log-odds-ratio the Thomsen index (Thomsen 1987).

The Thomsen index has the advantage over the Alford index in that it is insensitive to changes in the general popularity of the political parties. However, in practice, for two by two class voting tables the advantages of the Thomsen index over the Alford index should not be overstated. As the arguments given by Goodman (1975:86) imply, it is only when the distribution of the general popularity of political parties or the distribution of social classes is more skewed than 25:75 or 75:25, that the Alford and Thomsen indices might yield substantially different conclusions. In our data sets such distributions only occur in Canada and Ireland, where left-wing parties have less than 25 per cent of the votes. Consequently, in the aggregated country data set the Pearson correlation between the Alford and the Thomsen indices of the 324 years in the twenty countries has the value $0.97(p=0.000)$.

\section{EGP class voting}

To measure levels of class voting using the EGP class scheme, log-odds-ratios can also be applied. Here the advantages of the log-odds-ratio over the Alford index are more relevant, since in this case the distribution of the classes and the voting behaviour are regularly more skewed than 25:75 (Heath et al. 1985; Hout et al. 1995). Using our seven class EGP scheme it takes six logodds-ratios to measure all the differences in voting behaviour (left/right) between these classes. However, as proposed by Hout et al. (1995) the standard deviation of these log-odds-ratios can be used as an overall measure of the level of EGP class voting. They named this overall measure the kappa index.

A drawback of this kappa index is that it does not take into account that in some classes there are more respondents than in others, and thus that some log-odds-ratios are more robust than others. Therefore, we also use the delta index measuring the overall level of class voting, when using the EGP class scheme. This delta index is a parameter that results from specially designed loglinear models. These so-called 'uniform difference' models, developed by Erikson \& Goldthorpe (1992) and Xie (1992), provide a single parameter as a measure of the level of EGP class voting for a country in a specific year. In these models it is assumed that differences between all classes in their voting behaviour, measured by log-odds-ratios, vary uniformly by a constant proportion across countries and years. ${ }^{3}$ The models are fully equipped to examine the relationship between class and voting behaviour net of changes in the sizes of the classes and the popularity of the parties. 


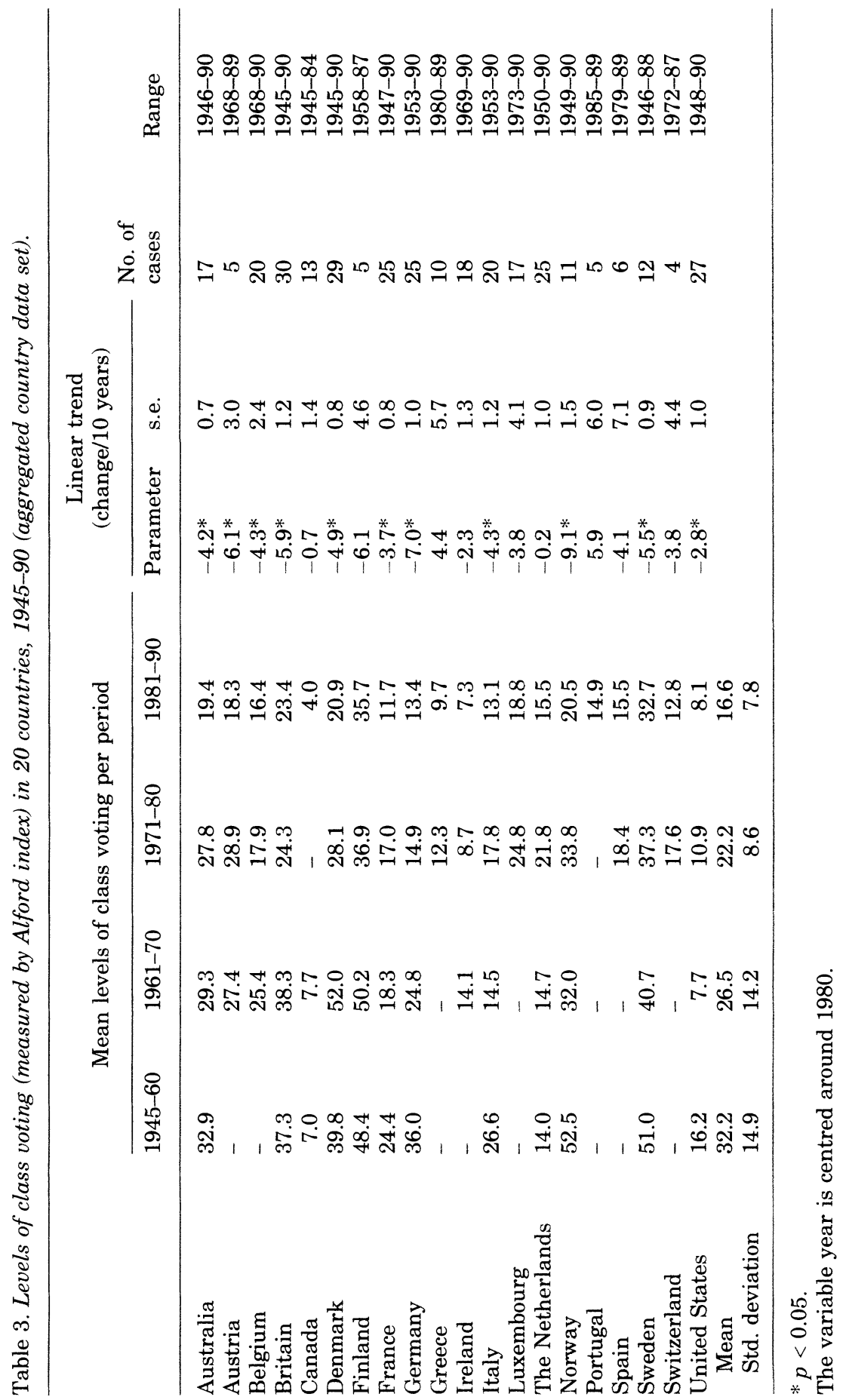


The general uniform difference model, can be represented by the following equation:

$$
\begin{aligned}
& \log ((\text { Left }) /(1-\text { Left }))= \\
& \beta_{0 \mathrm{jk}}+\delta_{\mathrm{jk}} *\left[\beta_{1} *(\text { Skilled manual class })+\beta_{2} * \text { (Agric. labourers }\right)+ \\
& \left.\left.\beta_{3} * \text { (Routine non-manual class }\right)+\beta_{4} * \text { (Service class }\right)+ \\
& \left.\beta_{5} * \text { (Petty Bourgeoisie }+\beta_{6} * \text { (Farmer) }\right]
\end{aligned}
$$

where the variable for the voting behaviour of the respondents, Left, is coded (1) when respondents vote for a left-wing party and (0) when they vote for a right-wing party. Furthermore, in this equation the seven EGP classes are represented by six dummy variables. The unskilled manual class is defined as the reference category. Consequently, the $\beta_{1}$ - to $\beta_{6}$-parameters represent the average differences in voting behaviour, measured by log-odds-ratios, between the unskilled manual class and the other EGP classes. According to the equation, the intercept, $\beta_{0 \mathrm{jk}}$ represents the log-odds for unskilled manual workers of voting for a left-wing rather than a right-wing party. This intercept is allowed to vary over years $(j)$ and countries $(k)$ in order to control for the variations in the general popularity of left-wing parties in the various countries and years. This parameter, however, is of limited interest because our concern is with class differences in voting behaviour and not with the absolute popularity of left-wing and right-wing parties. Our main interest lies in the delta indices, i.e. the $\delta_{\mathrm{jk}}$-parameters of the model. Under the fitted model, the delta indices give a measure of the overall differences and changes in the strength of the relationship between class and voting behaviour. They therefore show in which direction and to what extent class differences in voting behaviour uniformly (i.e. by a constant proportion) vary across years (j) and countries (k). Thus, these delta indices can be regarded as the overall level of class voting in a specific year in a specific country.

\section{Manual/non-manual class voting}

In order to answer our research questions posed, i.e. to describe levels of class voting in postwar societies, we start by computing both Alford and Thomsen indices for all years and countries data that were available in our aggregated country data set. Although we follow the theoretical considerations of scholars of the third generation (Heath et al. 1985; Hout et al. 1993) in regarding the Thomsen indices as a better measure of class voting than the Alford index, it is of interest to examine to what extent empirical testing does yield different results using both indices. We have already argued that in practice, for two by two class/vote tables, the advantages of the Thomsen index over the Alford index should not be overstated. This idea is confirmed by our analyses. The descriptions using both indices yield very much the same conclusions.

\section{Differences between countries}

To examine the differences in class voting between countries - and in order not to be too dependent on single cross-tabulations and thus open to the influence of peculiarities in the data - we calculated the mean value of the Alford and Thomsen indices of each country in four periods. These mean 


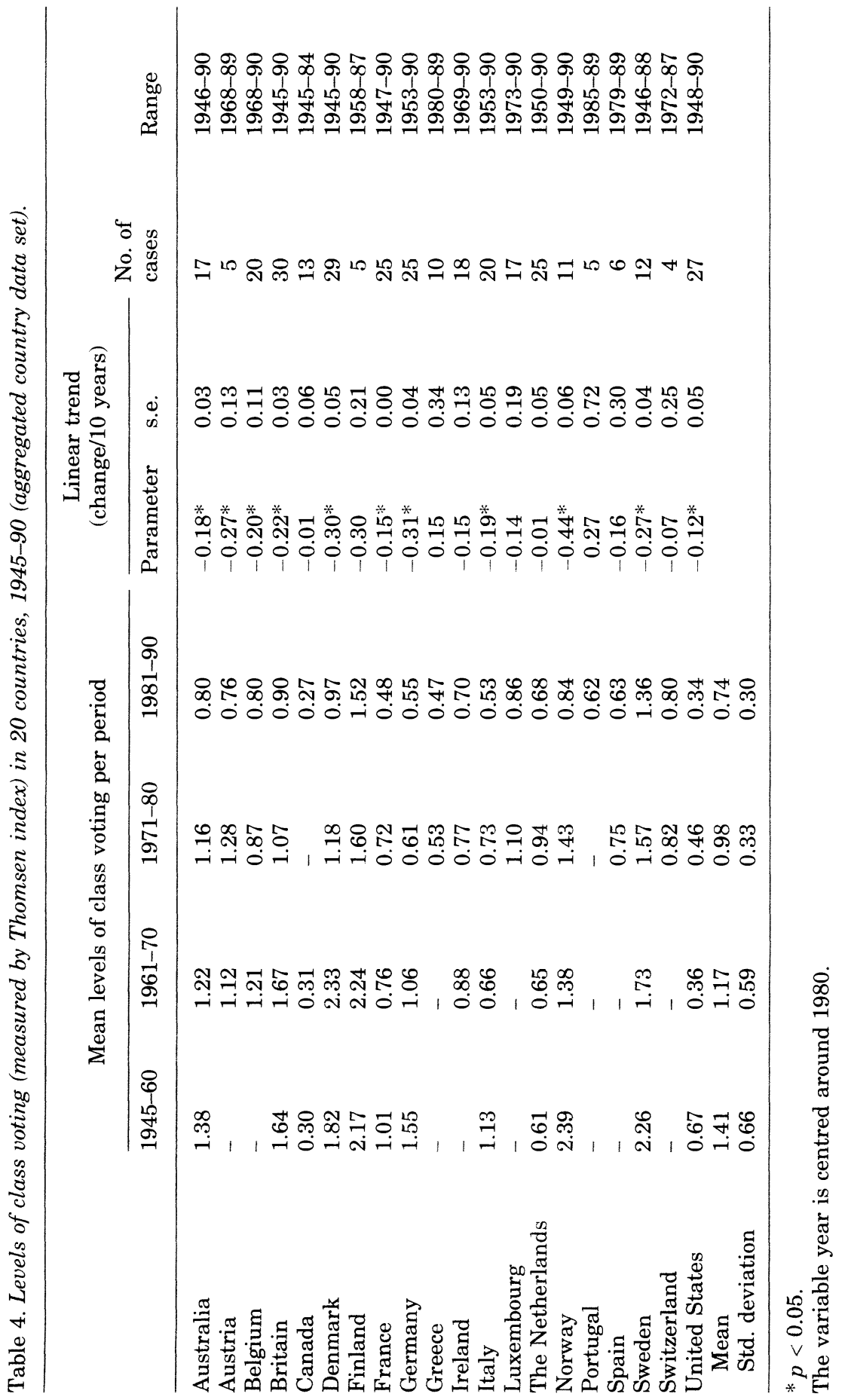




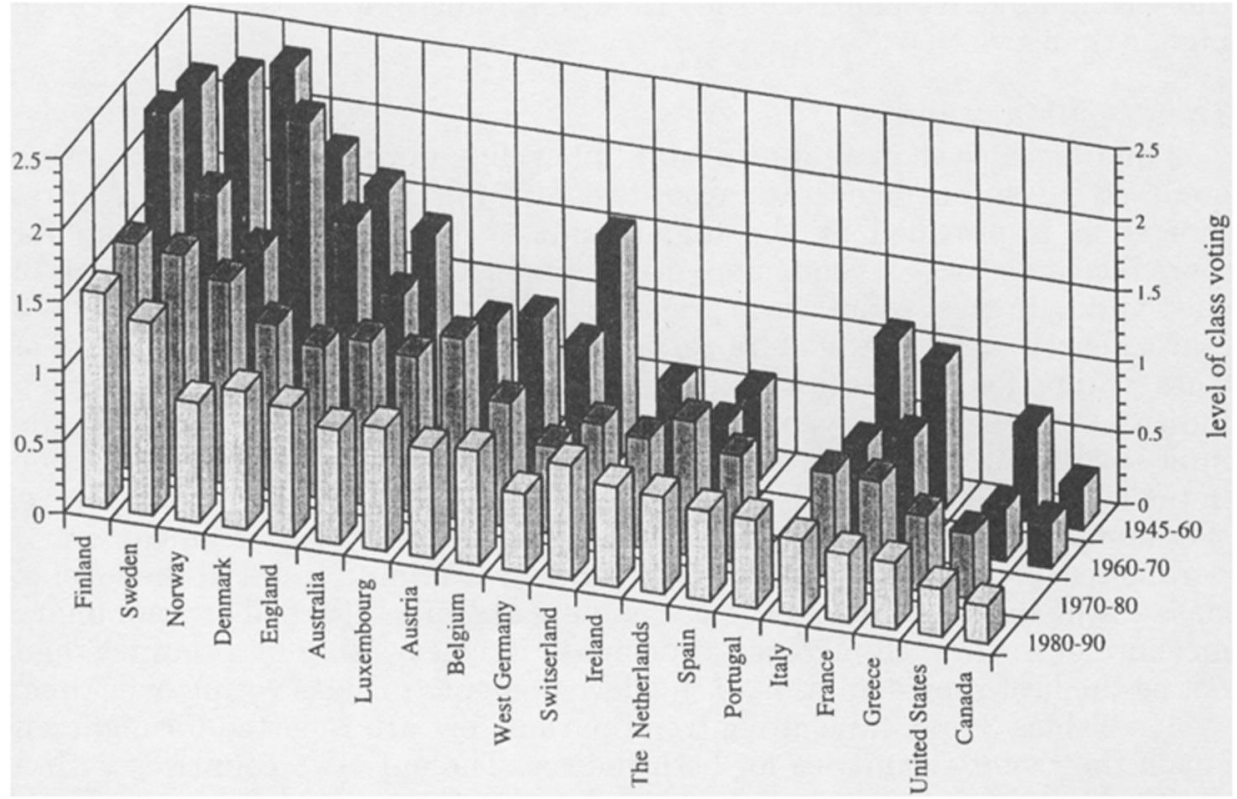

Fig. 1. The level of class voting (measured by Thomsen indices) in 20 countries, 1945-1990.

values are given in Tables 3 and 4 . Not surprisingly, when taking into account the high correlation between the values of the two indices, the rankings of the countries on both measures of class voting in all four periods are very similar. We therefore restrict ourselves to presenting only the mean values of the Thomsen indices in Figure 1.

Our analyses confirm the findings of previous, more limited studies that use only Alford indices. That is, there is a clear indication of substantial differences in levels of - both absolute and relative - manual/non-manual class voting across democratic industrialized countries in the postwar period. The lowest levels of class voting are found in the United States and Canada. In these countries we find low positive Thomsen indices. This implies that manual workers do vote more left-wing than non-manual workers, but the difference in voting behaviour between these classes - especially in Canada is small. The Thomsen indices of these countries rarely exceed 0.50. Furthermore, some countries have somewhat higher, but still relatively low levels of class voting. These countries are France, Greece, Ireland, Italy, The Netherlands, Portugal, Spain, Switzerland. In these countries, the Thomsen indices are rarely larger than one. Then follows a group of countries with intermediate levels of class voting: Australia, Austria, Belgium, Germany and Luxembourg. In these countries the Thomsen indices have predominantly a value between 1 and 1.5. Finally, in some countries we find relatively high levels of class voting, the Thomsen indices are higher than 1.5. These countries are the four Scandinavian countries and Britain. In 
the Scandinavian countries the Thomsen indices are occasionally even higher than two.

\section{Trends within countries}

Our findings also show that a substantial decline in the levels of class voting occurred in most democratic countries in the postwar period. A first indication is provided by the higher indices for earlier periods than for more recent years. A second, more precise indication of the decline in levels of class voting in most countries is provided by the trend parameters in Tables 3 and 4. These trend parameters report the decline - or rise - in the level of class voting for each country measured by Alford indices and Thomsen indices. For every country, a linear regression analysis was performed on the indices with the exact year of observation as independent variable. A decline in the level of class voting should be indicated by a negative trend parameter. We should point out that we do not argue that a negative linear trend parameter for a country implies a strict linear declining trend in the level of class voting in that country. The parameters are only regarded as a summary measure of the overall increase or decrease in class voting in a country, and not as the best representation of the developments in class voting over time.

In Tables 3 and 4, negative trend parameters are reported for eighteen out of the twenty countries for both indices. The only two countries with a positive (non-significant) trend-parameter are Greece and Portugal. However, for these two countries data are only available over the periods 1980-90 and 1985-90 respectively. Of the eighteen slope parameters that are negative in both tables, eleven are statistically significant at the 0.05 level. The pertinent countries are: Australia, Austria, Belgium, Britain, Denmark, France, Germany, Italy, Norway, Sweden, and the United States. Furthermore, the fact that we find statistically insignificant slope parameters for Finland, Spain and Switzerland might be caused by the fact that for these countries we have data for only a limited number of years. Thus, in general, our data lend support to the statement that levels of class voting in Western industrialized societies have declined over the postwar period. The only countries for which we do not find significant declines in their levels of class voting, but where we have data for a sufficient number of years to detect significant trends, are Canada, Ireland, Luxembourg and The Netherlands. ${ }^{4}$

If we compare the trend parameters for the Alford indices with those for the Thomsen indices we find that the ranking of the countries is almost identical. $^{5}$ The figures show that of all the countries featured in this study, Norway displays the strongest absolute decrease in manual/non-manual class voting, followed by the other Scandinavian countries. In Germany and Britain substantial absolute decreases in the Thomsen indices are also found. In the other countries the decline in class voting is less marked, whereas in Canada and the United States hardly any trend emerges.

\section{EGP class voting}

\section{Kappa-indices}

The next question that can be raised - and that has been raised frequently by scholars of the third generation of research on social stratification (Heath et 
al. 1985; Hout et al. 1993) - is to what extent the above results on crossnational and over-time patterns of class voting would be different if a more detailed class scheme would be used. Heath et al. (1985), Hout et al. (1993) and Goldthorpe (1994), for instance, posit that in industrialized countries declines in the levels of class voting, when measured by a manual/nonmanual class distinction, can - at least to some extent - be explained by changes in the composition of these two classes. In recent years many countries have seen the service class grow substantially relative to the other non-manual sub-classes. In addition, the percentage of skilled workers within the manual class has grown and the percentage of unskilled workers has diminished. These developments in a country will, under the conditions that members of the service class tend to be more left-wing than the other non-manual sub-classes, and the skilled workers are less left wing than the other manual sub-classes, lead toward a more left-wing non-manual class, a less left-wing manual class and a lower level of manual/non-manual class voting. Analysis of levels of class voting using a more detailed class scheme and thus controlling for changes in the composition of the manual and nonmanual class - therefore might show less pronounced declines in class voting.

To examine levels of EGP class voting, in Table 5 we present mean logodds-ratios representing the differences in voting behaviour between the EGP classes for sixteen countries and for four periods. These log-odds-ratios were calculated based on our individual level data. In this table the classes are ordered from the generally most left-wing class, the unskilled manual workers, to the typically least left-wing class, the farmers. When calculating the log-odds-ratios, the unskilled manual class was chosen as the reference category. Consequently, the calculated log-odds-ratios represent the difference in voting behaviour between the unskilled manual class and the other classes. Furthermore, kappa indices (the standard deviations over the displayed log-odds-ratios) are presented in Table 6 as a measure of the overall level of EGP class voting in each period in each country.

The measures of EGP class voting in Tables 5 and 6 reveal that very much the same picture comes up as when describing levels of class voting using a manual/non-manual class distinction. Again, the differences in voting behaviour between the classes vary substantially from country to country. Furthermore, the ranking of the countries with respect to levels of class voting is similar to the ranking for manual/non-manual class voting. ${ }^{6}$ For example, in Norway during the period 1971-80 the difference between the most left-wing class and the most right-wing class, that is between the unskilled manual workers and the farmers, is 2.75, while in the United States for the same period the difference between these classes is only 0.97. Besides, in each of the distinguished periods the countries from the continent of North America (Canada and the United States) have the lowest kappa indices, while Britain and the Scandinavian countries have the highest.

To investigate whether the level of EGP class voting has declined over the postwar period like the levels of manual/non-manual class voting in these countries, we examine the linear trend parameters for the kappa indices that are also given in Table 6. These figures show negative trend-parameters for all countries under investigation, except Austria. Thus, we can carefully conclude that - similar to the developments in levels of manual/non-manual 


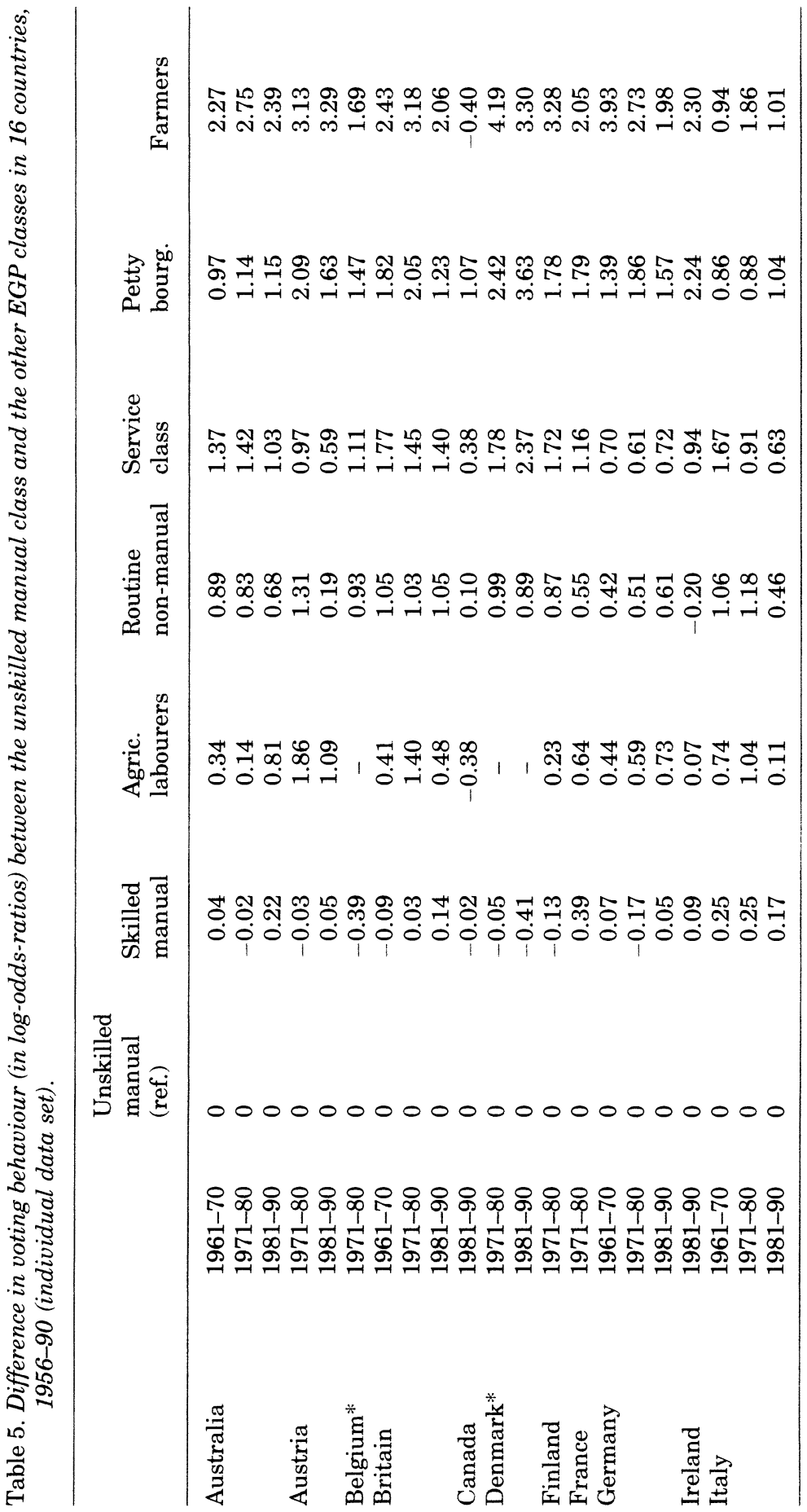




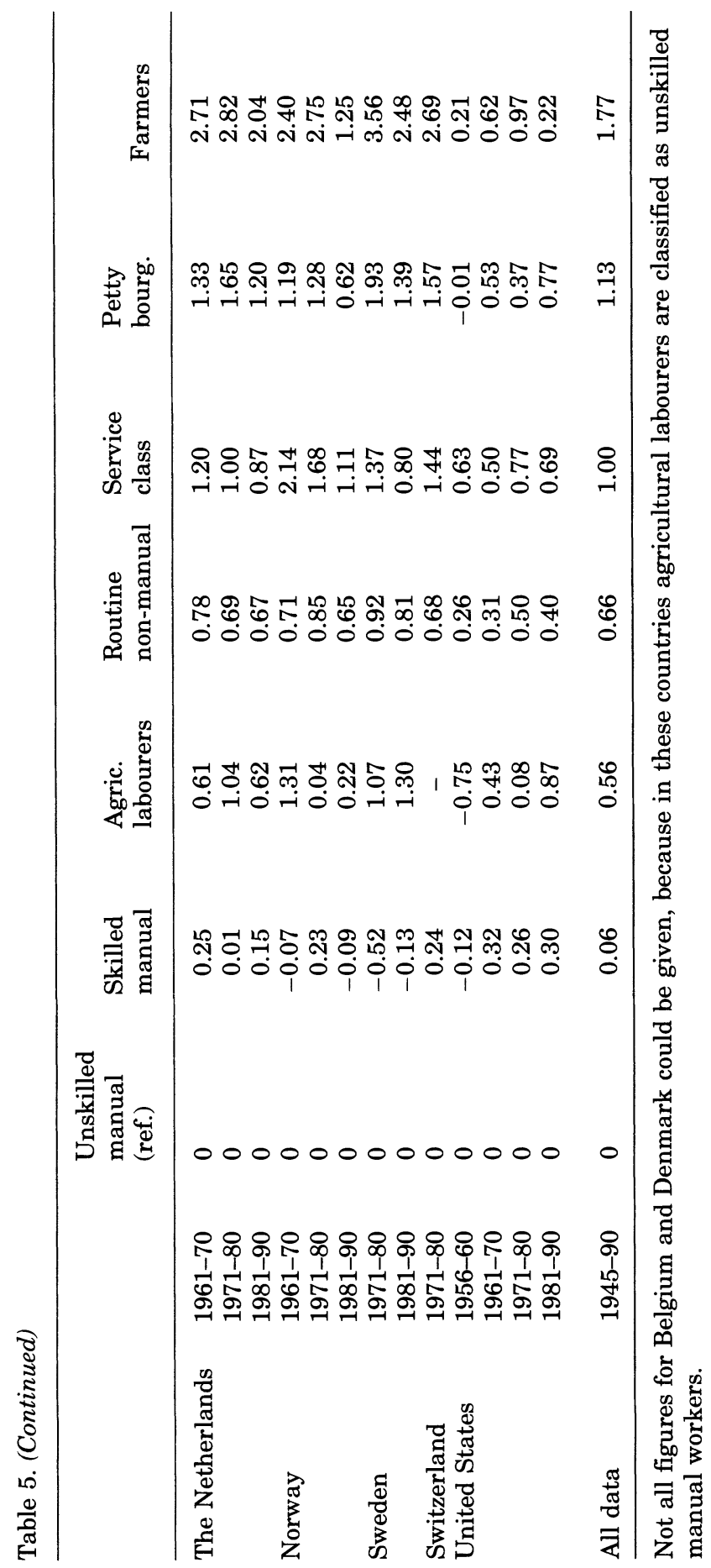


class voting - declines in the levels of EGP class voting in most countries have occurred. The trend parameters differ significantly from zero in Germany, Britain, and Norway only. The fact that some trend parameters are not statistically significantly different from zero again might be due to the fact that for the pertinent countries only a limited number of data sets were available. It is only for the United States and The Netherlands, i.e. countries where we have data from more than 10 years, that we can be reasonably sure that no systematic decline in EGP class voting has occurred.

\section{Delta-indices}

However, when using log-odds-ratios (and kappa indices) we have to realize that the log-odds-ratios each are based on different number of respondents, and that consequentially the estimates of the log-odds-ratios differ in reliability. Therefore, to describe the levels of EGP class voting in the countries in the period 1956-90, we also use delta indices. These indices $\left(\delta_{\mathrm{jk}^{-}}\right.$ parameters) result from applying the above discussed uniform difference models to our individual level data.

To test statistically whether the overall levels of class voting differed significantly across countries and whether significant trends had occurred within these countries, some variations of the uniform difference models were applied. Each model gives a different representation of the country differences and trends (see Table 7). To select the model that summarizes our data best, we compared the fit of one model with the fit of a less general one nested within the first. The traditional Likelihood-ratio test and the BIC (Bayesian Information Coefficient) were used to detect whether the fits of models differed significantly. When comparing several models, the one with the most negative BIC is the model to be preferred. Furthermore, the BIC shows whether a model describes the data reasonably. In that case the BIC takes a negative value.

We used both the Likelihood-ratio test and the BIC statistic, since both have advantages over the other measure. On the one hand, the BIC statistic has the advantage over the Likelihood-ratio test in that it takes into account the number of cases in the analyses. To select between two models, when analysing a large data set (as we do in this article) and using the Likelihoodratio, differences between models can too easily turn out to be statistically significant (Raftery 1986). On the other hand, the BIC statistic has the disadvantage over the Likelihood-ratio test that it is biased in favour of parsimony as against fit (Erikson \& Goldthorpe 1992:101). The addition of a parameter to a model resulting in a substantial refinement in the representation of the data might not yield a smaller BIC, but might yield a significant improvement in the Likelihood-ratio.

We first fitted the Independence model (A), which assumes that there is no association between class and voting behaviour in all countries and years. The second model applied, the No difference model $(B)$, presumes that in general there is an association between class and vote, but that the strength of this association is the same in all countries and years. Not surprisingly, when we consider our earlier findings, this model provides a much better representation of the data than does the first model $\left(\Delta \mathrm{L}^{2}=4919.8, p=0.000\right.$; $\Delta \mathrm{BIC}=-4852.4)$. Furthermore, the large negative BIC indicates that this 


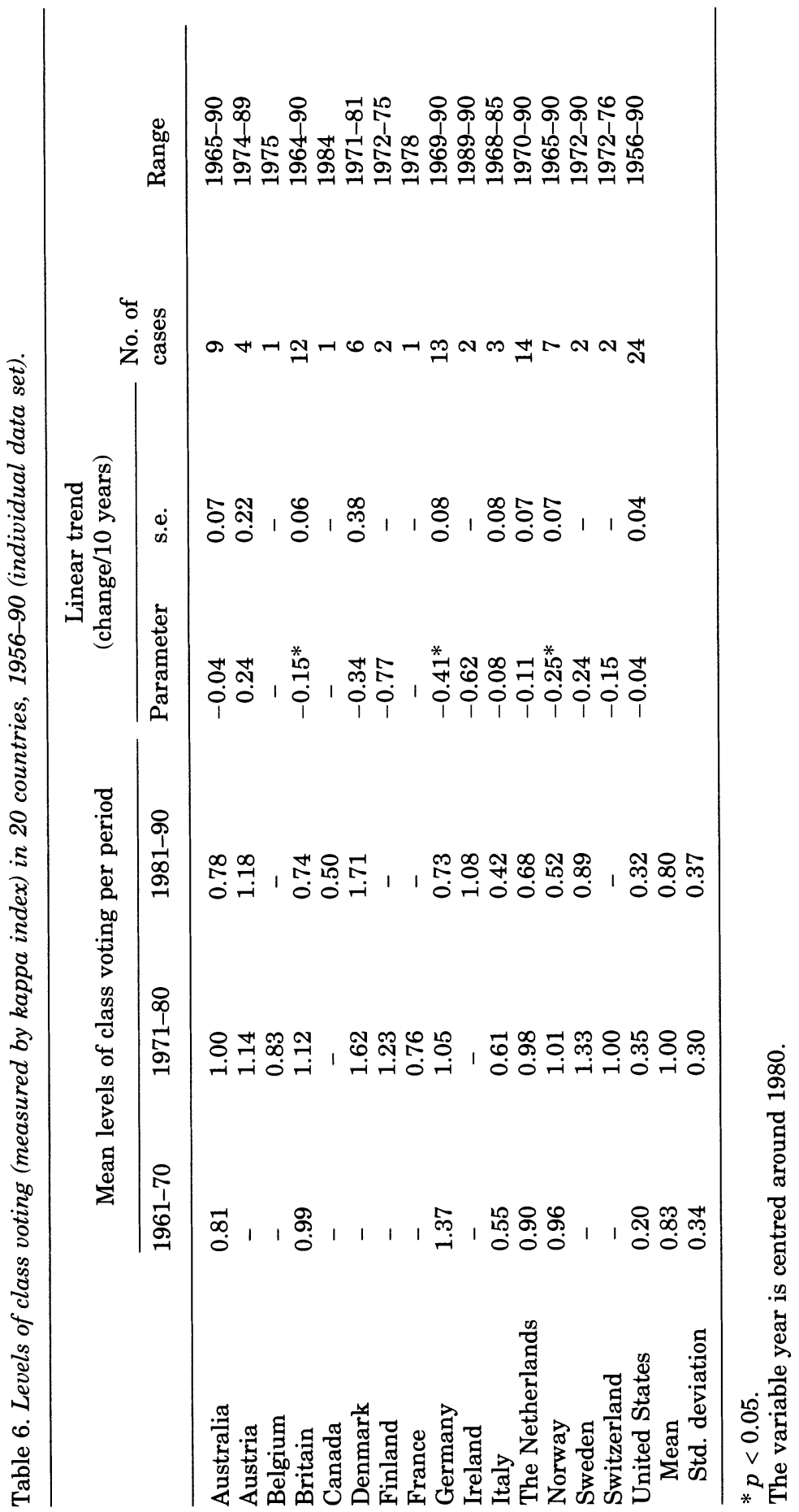


model gives a good representation of the data. Subsequently, we tested whether levels of class voting differed between countries, using the country differences model $(C)$ that assumes that the levels of class voting are constant over-time, but that they vary across countries. This model provides a significantly better fit than model $\mathrm{B}\left(\Delta \mathrm{L}^{2}=805.4, p=0.000 ; \Delta \mathrm{BIC}=-636.9\right)$. Thus, we can accept that the sixteen countries under investigations differ in their levels of class voting.

Next, we tested for the occurrence of trends in levels of class voting within countries. First, using the country differences and general linear trend model $(D)$, we examined whether we could detect a general linear trend in all countries in their levels of class voting. This model represents the data significantly better than the preceding models $\left(\Delta \mathrm{L}^{2}=49.7, p=0.000\right.$; $\Delta \mathrm{BIC}=-38.4)$. Therefore, on the basis of the fit statistics and the estimated general trend parameter (i.e. -0.014 , s.e. $=0.002$ ) we provisionally conclude that in general a decline in levels of class voting has occurred in the countries featured in this chapter. Second, employing the country differences and country specific trends model $(E)$, we tested whether these linear trends differed among countries. This model shows a significant improvement in fit according to the Likelihood-ratio test $\left(\Delta \mathrm{L}^{2}=64.7, p=0.000\right)$, but the BIC has less negative value than the previously employed model $(\triangle \mathrm{BIC}=-81.3)$. However, since the values of BIC for both models are not very different, and the BIC statistic is biased in favour of parsimony as against fit, we conclude that it is very possible that the BIC comparison does not detect that in some countries substantially different trends occurred. Therefore - and because our interest is not just to give the most parsimonious representation of the data, but also to give a fair description of the processes of realignment in all countries and periods - we do not decide in favour of or against model D or model E. Finally, we employed the country difference and country specific non-linear trend model $(F)$, assuming that in each country a different non-

Table 7. Results of fitting uniform difference models to class voting data for 16 countries.

\begin{tabular}{|c|c|c|c|c|c|c|}
\hline & & $\mathrm{L}^{2}$ & $\mathrm{df}$ & $\mathrm{rL}^{2}$ & $\mathrm{BIC}$ & DI \\
\hline A. & Independence model $\left(\delta_{\mathrm{jk}}=0\right)$ & 6567.9 & 612 & 0 & -308.3 & 12.0 \\
\hline B. & No differences model $\left(\delta_{\mathrm{jk}}=1\right)$ & 1648.1 & 606 & 74.9 & -5160.7 & 5.3 \\
\hline C. & Country differences model $\left(\delta_{\mathrm{jk}}=\delta_{0 \mathrm{k}}\right)$ & 842.7 & 591 & 87.2 & -5797.6 & 4.3 \\
\hline D. & $\begin{array}{l}\text { Country differences and general } \\
\text { linear trend }\left(\delta_{\mathrm{jk}}=\delta_{0 \mathrm{k}}+\delta_{1} * \text { Year }\right)\end{array}$ & 793.0 & 590 & 87.9 & -5836.0 & 4.1 \\
\hline E. & $\begin{array}{l}\text { Country differences and country- } \\
\text { specific linear trends } \\
\left(\delta_{\mathrm{jk}}=\delta_{0 \mathrm{k}}+\delta_{1 \mathrm{k}} * \text { Year }\right)\end{array}$ & 728.3 & 577 & 88.9 & -5754.7 & 4.0 \\
\hline F. & $\begin{array}{l}\text { Country differences and country- } \\
\text { specific non-linear trends }\left(\delta_{j \mathrm{k}}=\delta_{\mathrm{jk}}\right)\end{array}$ & 622.1 & 504 & 90.5 & -5040.7 & 3.5 \\
\hline
\end{tabular}

No. of cases $=75,783 ;$ df: Degrees of freedom; $\mathrm{L}^{2}$ : Likelihood-ratio; $\mathrm{rL}^{2}$ : Percentage reduction in the $\mathrm{L}^{2}$ compared to the independence model; BIC: Bayesian Information Coefficient; BIC $=\mathrm{L}^{2}-\mathrm{df}_{\mathrm{used}} * \log (\mathrm{N})$; DI: Dissimilarity index, showing the percentage of all cases in the tables analysed that are misclassified - that is, allocated to the wrong cell by a particular model. 


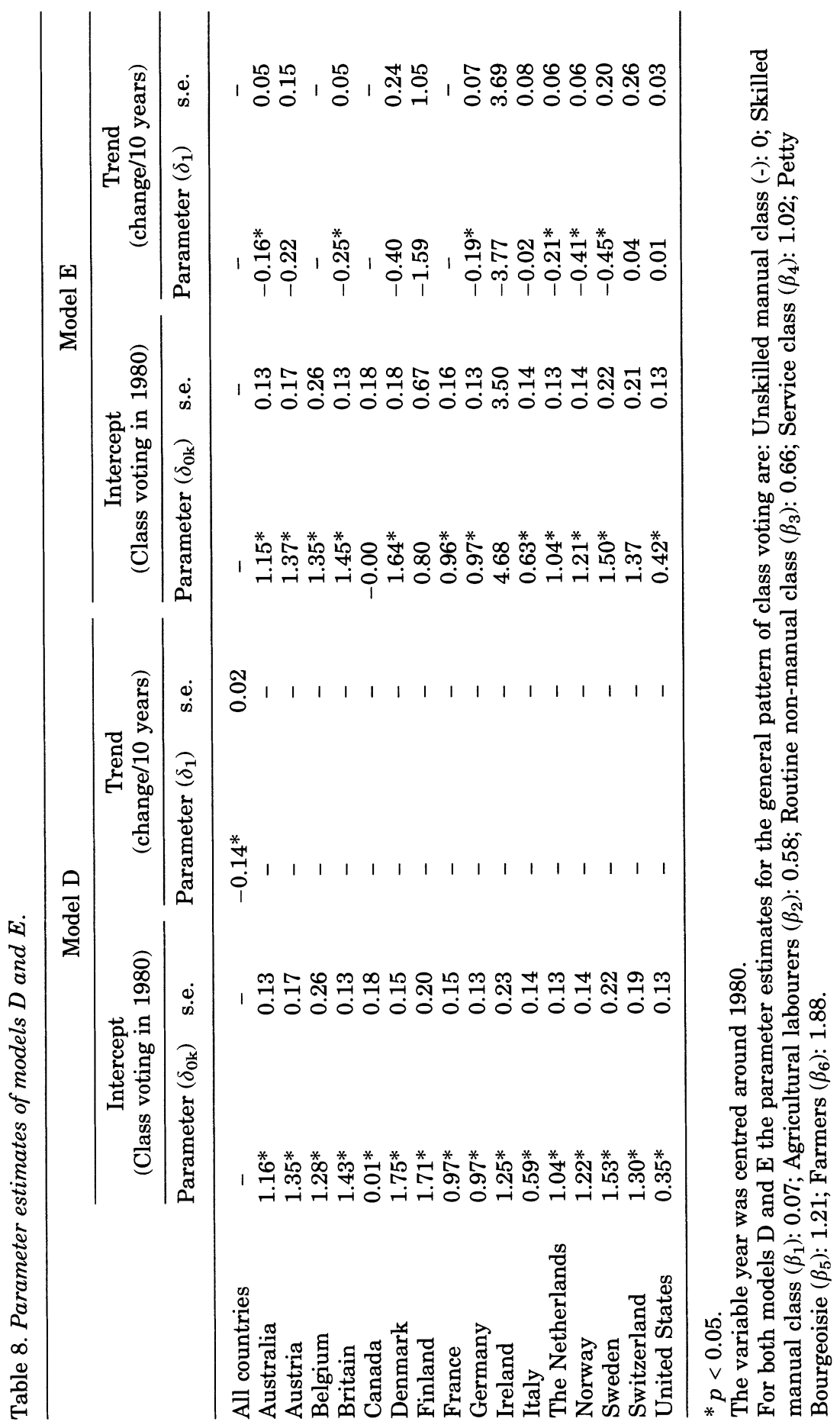


linear trend has occurred in levels of class voting. The estimated country and year specific $\delta \mathrm{jk}$-parameters of model $\mathrm{F}$ (not given) reveal that in all countries, with the exception of the United States and Switzerland where a small increase in class voting is found, in general a fairly monotonic decline in the countries' levels of class voting has occurred, but that around this trend fluctuations are visible. Although it gives the best representation of our data according to the Likelihood-ratio test $\left(\Delta \mathrm{L}^{2}=170.9, p=0.007\right)$, this model's BIC has such a high value compared to models $\mathrm{D}$ and $\mathrm{E}$ $(\triangle \mathrm{BIC}=795.3$ and 714.0$)$, that we regard models $\mathrm{D}$ and $\mathrm{E}$ as the most parsimonious adequate representation of our class voting data. ${ }^{7}$

\section{General pattern of class voting}

The parameter estimates of the preferred models, (models D and E) are presented in Table 8 . In the lower part of this table, the estimates of the $\beta_{1}$ - to $\beta_{6}$-parameters for the models are presented. These represent the general pattern of association between the EGP classes and their voting behaviour, i.e. measured as the differences in voting behaviour between the unskilled manual class and the other EGP classes. According to the estimates of the $\beta$ parameters, the difference between the unskilled manual class and the skilled manual class is 0.07 , while between the unskilled manual class and the farmers it is 1.88 . The pattern of class voting obtained from the estimated $\beta$-parameters is - as might be expected - almost identical to that found in the last row of Table 5 where we calculated log-odds-ratios on class voting tables based on our total data set.

\section{Difference between countries}

The levels of class voting in the countries are represented by the country parameters, i.e. the $\delta_{0 \mathrm{k}}$-parameters. These parameters are presented in the main part of Table 8. Because in the models the variable Year was linearly transformed by subtracting 1980 from its original value, the estimates of the country parameters represent the differences in the levels of class voting between countries in 1980 . The interpretation of the parameters (model E) is that, for example, in Norway all log-odds-ratios are 1.21 times that in the general pattern. Hence, in that country in 1980 the log-odds-ratio indicating the differences in voting behaviour between the unskilled manual workers and the service class yields $1.21 * 1.02=1.24$. The parameters for the United States imply that all log-odds-ratios in the United States are 0.42 times smaller than in the general pattern. The parameters also allow comparison between countries. For example, the parameters indicate that in Norway all log-odds-ratios are 1.21/0.42, or 2.9 times, larger than in the United States.

The country parameters indicate that levels of class voting differed substantively from country to country in $1980 .{ }^{8}$ Denmark, Sweden, and Britain are the three countries with the highest levels, followed by Austria, Switzerland, Belgium, Norway and Australia. The countries with low levels of class voting are The Netherlands, Germany, France, Finland, and Italy. The two countries with the lowest levels are the United States and Canada. Thus, again, it can be concluded that the ranking of the countries, when 
measured by the EGP class scheme, is fairly similar to the ranking of the countries when using the traditional manual and non-manual class scheme.

\section{Trends}

The estimated trend parameter $\left(\delta_{1}\right)$ of model $\mathrm{D}$, the country difference and general trend model, represents the general linear trend in levels of class voting within all countries. This parameter takes the negative value -0.14 (s.e. 0.02), which implies a decline in the association between class and vote. More particularly, all the log-odds-ratios representing the difference in voting behaviour between the EGP classes, i.e. the $\beta_{1^{-}}$to $\beta_{6}$-parameters, decrease by 14 per cent points per decade. This has serious implications for the levels of class voting. For example, it means that in Norway the log-oddsratio representing the difference in voting behaviour between the unskilled manual workers and the service class, which has the value 1.24 in 1980 , will in the year 2000 only be: $1.24-(2 * 0.14 * 1.24)=0.92$.

The trend parameters of model $\mathrm{E}$, the country difference and country specific linear trends model, make it possible to check whether or not trends differed from country to country. These country-specific trend parameters, the $\delta_{1 \mathrm{k}}$-parameters, represent the linear trends in class voting within the countries. Table 8 shows that in eleven out of the thirteen countries the country-specific trend parameter has a negative value. Switzerland and the United States have positive trend parameters, but the standard errors of these are so large that no definite conclusions of an increase in class voting can be drawn. Of the negative trend parameters six are statistically significant, i.e. for Australia, Britain, Germany, The Netherlands, Norway and Sweden. The strongest declines (ignoring Ireland where our two years of survey are too close to interpret trends) are found in Finland, Norway and Denmark. Obviously, for those countries for which we have many data sets over a longer period of time we have a higher chance of finding a significant trend.

To examine whether the trends in class voting, when measured by the EGP class scheme, are comparable to the trends in class voting measured by the manual/non-manual class scheme, we compare the linear trend parameters in Table 8 with the linear trend parameters concerning manual/non-manual class voting presented in Tables 3 and 4 . A comparison of the trend parameters for the manual/non-manual class voting with those for the EGP class voting shows that in all countries, except Switzerland and the United States, a declining trend is found, both when focusing on manual/ non-manual class voting and on EGP class voting. Furthermore, in general the larger the decline in manual/non-manual class voting, the larger the decline in EGP class voting. This is illustrated by the positive correlations between the trend parameters from Table 3 and Table 8 (Pearson correlation: $0.48, n=11, p=0.134$; leaving Finland and Ireland aside), and between the entries of Table 4 and Table $8(0.67, n=11, p=0.024)$.

Concluding, although measuring class voting with EGP classes and logodds-ratios is theoretically preferable, descriptions of the levels of class voting using both class schemes in general result in the same ranking of the countries with respect to levels of class voting and the amount of decline. 


\section{Conclusions}

From the very beginning of research on class and voting behaviour, studies have shown that the strength of the relationship between class and voting behaviour differed between countries. In addition, these studies have revealed that the strength of that relationship declined over the postwar period in most of these countries. These conclusions were especially drawn in studies of the first generation of social stratification and politics. In these studies levels of class voting were measured on the basis of so-called 'Alford indices', which distinguish only between manual and non-manual classes and measure absolute differences in voting behaviour. However, in studies of the later generation doubts were raised about the conclusions of these first generation studies. It was claimed that differences detected, when using measures of absolute class voting like the Alford index, might not (solely) be due to differences in the strength of the relationship between class and voting behaviour, but also to differences in the general popularity of the political parties. Furthermore, it was argued that differences between countries or periods detected when using the manual/non-manual class scheme, might to some extent be due to differences in the composition of the manual and non-manual classes between countries or periods, and not (only) to differences in the strength of the relationship between class and voting behaviour. Consequently, in third generation studies it was argued that when using a measure of relative class voting and distinguishing between more detailed classes, descriptions of levels of class voting might lead to different conclusions about between-country and over-time differences in class voting.

In the present study we tested the tenability of these arguments. The main finding is that the various measures of class voting yielded the same conclusions with respect to the ranking of the countries according to their levels of class voting, and according to the speed of declines in class voting. The results indicated that substantial differences in levels of relative class voting existed between democratic industrialized countries in the postwar period. Of all countries under investigation, the Scandinavian countries and Britain had the highest levels of class voting, and the United States and Canada the lowest. In addition, our analyses showed that in many of the countries substantial declines in levels of class voting occurred in the postwar period. The fluctuations in class voting within countries, in our view, can in most of these countries - with the exception of the United States and Switzerland - be regarded as part of an overall declining trend, and not as trendless fluctuations (see Heath et al. 1985). The declines were largest in the Scandinavian countries, followed by Germany and Britain. Moreover, we found no evidence of substantial declines in EGP class voting in Canada, Ireland, Luxembourg, Switzerland and The Netherlands. This, despite the fact that for these countries data over a considerable time period were available.

These results, however, do not imply that the claims of the scholars of the third generation were wrong. Our findings revealed that some of the between-country and over-time variations in manual/non-manual class voting were due to variations in the composition of the manual and nonmanual classes, and not only to variations in the strength of the relationship 
between class and voting behaviour. Furthermore, we did not fully use the possibilities offered by our data set and detailed class scheme. To begin with we dealt with a question that pertains only to the overall levels of class voting in countries. We thus did not examine the voting behaviour of these detailed classes separately, nor did we investigate the specific trends in the voting behaviour of these different classes. Such class-specific trends are of interest, since - as for example supposed for Britain by Heath et al. (1991) some classes might have started to vote less in accordance with their class interest, while others might have kept the same voting pattern or even started to vote more in accordance with their class interests. These separate class-specific trends cannot always fully be detected when investigating the overall levels of class voting. Therefore, in future studies the focus should not be restricted to overall levels of class voting, but should also be on classspecific voting behaviour.

In addition, having established that there have been substantial differences in overall levels of relative class voting between Western industrial countries in the postwar period, and that during the same period significant declines occurred in class voting levels within these countries, future studies should focus on explaining these differences and trends. Various studies of stratification and politics from the first up to and including the third generation have suggested how social and political characteristics affect levels of class voting in countries (Lipset 1983; Manza et al. 1995; Nieuwbeerta 1995). The social characteristics raised by such studies range from variations in religious and ethnic diversity, via rises in the general standard of living and levels of intergenerational mobility, to post-materialistic value orientations. The political characteristics concern, among other things, the prominence of class issues in politics, and the differences in policy preferences between political parties. The links between these social and political characteristics of countries and their levels of class voting need attention in future studies.

When testing political explanations for variation in levels of class voting in future studies, it would be worthwhile to distinguish between all the separate political parties that run in a country's elections. This would facilitate discovering whether substantial changes in the voting patterns of social classes have occurred within left-wing or right-wing political blocks. For example, it might be that in The Netherlands - a country where we did not find a systematic decline in class voting - the manual workers are just as likely to vote for left-wing parties as before, but are less apt to vote for extreme left-wing parties, choosing instead more moderate left-wing parties. Evans et al. (1991) and Heath et al. (1985, 1995) have already applied more detailed party classifications when investigating trends in Britain, while Hout et al. (1995) have done likewise for the United States, and Ringdal \& Hines (1995) for Norway. For trend analyses in other countries and for crossnationally comparable studies on class voting these examples deserve to be followed. 


\section{Acknowledgements}

This article is part of the author's Ph.D thesis (Nieuwbeerta 1995), which was written when he was affiliated to the Department of Sociology of the University of Nijmegen, The Netherlands, and was financed by The Netherlands Organization for Scientific Research (NWO Grants 500-179-001). The author expresses his gratitude to Jan van Deth, Mary Duffy, Nan Dirk de Graaf, Anthony Heath, John Hendrickx, Michael Hout, John Goldthorpe, Wout Ultee and two anonymous reviewers for comments on earlier drafts of the article, to Robert Erikson, John Hendrickx and Clive Payne for their help with applying the loglinear models to his data, and to Harry Ganzeboom for providing many data sets.

\section{Notes}

${ }^{1}$ The limitations introduced by such different measures of voting behaviour must be fully appreciated. However, various analyses using only surveys containing 'voting behaviour' measures, and several analyses using only surveys containing 'political preference' measures, did not result in significantly different outcomes. Furthermore, we do not know of any study which shows that the relationship between class and political preference is fundamentally different from that between class and voting behaviour.

${ }^{2}$ We prefer to use the log-odds-ratio over the odds-ratio, since the latter message does not adjust for floor effects. That is, if there is hardly a relationship between class and vote, a small change in the strength of that relationship results in a small alteration in the oddsratio, whereas if this relationship is strong, a small change results in a large alteration in this measure.

${ }^{3}$ One could argue that our detailed class scheme also enables us to distinguish between class-specific processes of dealignment or realignment. For example, it is possible that the distance between the service class and the skilled manual class becomes smaller, while at the same time the distance between the service class and the farmers grows. In this study, however, we focus on the overall change in levels of class voting and leave class-specific dealignment and realignment processes for future research (see also the conclusions section).

${ }^{4}$ Inspection of the indices for each year within these countries, shows that indeed hardly any decline in class voting occurred in these countries.

5 The Pearson correlation between the trend parameters in Tables 3 and 4 has the value $0.97(p=0.000)$.

${ }^{6}$ We also compared all EGP class voting outcomes with Alford and Thomsen indices based solely on our individual-level data set. This results in the same conclusions.

${ }^{7}$ Disaggregating the fit statistics for model D reveals that for 88 out of the 103 separate year/country 'EGP class voting tables' the model fits according to the classic criterion of statistical inference (i.e. $\mathrm{L}^{2} / \mathrm{df}$ ). The 15 tables for which we do not obtain a good fit on this criterion contain in general a relatively large number of cases. Furthermore, the BIC statistic results in a negative coefficient for 
101 tables. Only the 1970 United States data and the 1979 Australian data yield positive BICs. Hence, the model provides an adequate summary of the class voting pattern in almost all years in all countries.

8 The unusual country parameters of model E for Finland and Ireland are caused by the fact that for these countries we only had two data sets in a short period and that levels of class voting in these data sets/years differed substantially.

\section{References}

Abramson, P. R., Aldrich, J. H. \& Rohde, D. W. 1990. Change and Continuity in the 1988 Elections. Washington: CQ Press.

$\rightarrow$ Alford, R. 1962. A Suggested Index of the Association of Social Class and Voting. Public Opinion Quarterly, 26, 417-425.

Alford, R. 1963. Party and Society: The Anglo-American Democracies. Westport: Greenwood Press.

Alford, R. 1967. Class Voting in Anglo-American Political Systems. In S. M. Lipset \& S. Rokkan (eds.), Party Systems and Voter Alignments: Cross-National Perspectives, pp. 67-94. New York: Free Press.

Allardt, E. \& Littunen, Y. (eds.) 1964. Cleavages, Ideologies and Party Systems: Contributions to Comparative Political Sociology. Helsinki: Academic Bookstore.

Allardt, E. \& Wesolowski, W. (eds.) 1978. Social Structure and Change: Finland and Poland in Comparative Perspective. Warszawa: Polish Scientific Publishers.

Allum, P. A. 1979. Italy. In S. Henig (ed.), Political Parties in the European Community, pp. 135-169. London: Allen \& Unwin.

Andersen, J. G. 1984. Decline of Class Voting or Change in Class Voting? Social Classes and Party Choice in Denmark in the 1970s. European Journal of Political Research, 12, 243-259.

Anderson, D. \& Davidson, P. 1943. Ballots and the Democratic Class Struggle. Stanford: Stanford University Press.

Andeweg, R. B. 1982. Dutch Voter Adrift: On Explanations of Electoral Change 1963-1977. Ph.D. dissertation. Leyden: University of Leyden.

Baker, K. L., Dalton, R. J. \& Hillebrandt, K. 1981. Germany Transformed: Political Culture and the New Politics. Cambridge: Harvard University Press.

Bartolini, S. \& Mair, P. 1990. Identity, Competition and Electoral Availability: The Stabilisation of European Electorates, 1885-1985. Cambridge: Cambridge University Press.

Baxter, J., Emmison, M. \& Western, J. (eds.) 1991. Class Analysis and Contemporary Australia. Melbourne: Macmillan.

Berglund, S. 1988. The 1987 Eduskunta Election in Finland. Scandinavian Political Studies, 11, 69-76.

Books, J. W. \& Reynolds, J. B. 1975. A Note on Class Voting in Great Britain and the United States. Comparative Political Studies, 8, 360-376.

Butler, D. E. \& Stokes, D. E. 1974. Political Change in Britain: The Evolution of Electoral Choice (second edition). London: Macmillan. 
Campbell, A., Converse, P. E., Miller, W. E. \& Stokes, D. E. 1960. The American Voter. Chicago: University of Chicago Press.

Clark, T. N. \& Lipset, S. M. 1991. Are Social Classes Dying? International Sociology, 6, 397-410.

Clark, T. N., Lipset, S. M. \& Rempel, M. 1993. The Declining Political Significance of Social Class. International Sociology, 8, 293-316.

Converse, P. E. \& Pierce, R. 1986. Political Representation in France. Cambridge: Harvard University Press.

Crewe, I. \& Denver, D. (eds.) 1985. Electoral Change in Western Democracies: Patterns and Sources of Electoral Volatility. London: Croom Helm.

Crewe, I. 1986. On the Death and Resurrection of Class Voting: Some Comments on How Britain Votes. Political Studies, 34, 620-638.

Dalton, R. J. 1988. Citizens Politics in Western Democracies: Public Opinion and Political Parties in the United States, Great Britain, West Germany and France. Chatham: Chatham House Publishers.

Dalton, R. J., Flanagan, S. C. \& Beck, P. A. (eds.) 1984. Electoral Change in Industrial Democracies: Realignment or Dealignment? Princeton: Princeton University Press.

$\rightarrow$ De Graaf, N. D., Nieuwbeerta, P. \& Heath, A. 1995. Class Mobility and Political Preference: Individual and Contextual Effects. American Journal of Sociology, 100, 997-1027.

De Jong, J. J. 1956. Overheid en Onderdaan. Wageningen: Zomer \& Keunings.

Den Uyl, J. 1951. Verkiezingen in Nederland: De Ontwikkelingen en Verspreiding van Politieke Voorkeuren en hun Betekenis voor de Partij van de Arbeid. Amsterdam: Dr. Wiarda Beckman Stichting.

Erikson, R. \& Goldthorpe, J. H. 1992. The Constant Flux: A Study of Class Mobility in Industrial Societies. Oxford: Clarendon Press.

$\rightarrow$ Erikson, R., Goldthorpe, J. H. \& Portocarrero, J. 1979. Integenerational Class Mobility in Three Western European Societies: England, France and Sweden. British Journal of Sociology, 30, 415-441.

Evans, G., Heath, A. \& Payne, C. 1991. Modelling Trends in the Class/Party Relationship, 1964-1987. Electoral Studies, 10, 99-117.

Featherman, D. L., Hauser, R. M. \& Sewell, W. H. 1974. Toward Comparable Data on Inequality and Stratification: Perspectives on the Second Generation of National Mobility Studies. Current Sociology, 22, 383-397.

Forschungsgruppe Wahlen E.V. 1990. Bundestagwahl 1990: Eine Analyse der Ersten Gesantdeutschen Bundestagwahl. Mannheim.

Franklin, M. 1985a. The Decline in Class Voting in Britain: Changes in the Basis of Electoral Choice, 1964-1983. Oxford: Oxford University Press.

Franklin, M. 1985b. How the Decline in Class Voting Opened the Way to Radical Change to British Politics. British Journal of Political Science, 14, 483-508.

Franklin, M. N., Mackie, T., Valen, H. (eds.) 1992. Electoral Change: Responses to Evolving Social and Attitudinal Structures in Western Countries. Cambridge: Cambridge University Press. 
Frognier, A. P. 1975. Vote, Classe Sociale et Religion/Pratique Religieuse. Res Publica, 17, 479-490.

Ganzeboom, H. B. G., Luijkx, R. \& Treiman, D. J. 1989. Intergenerational Class Mobility in Comparative Perspective. Research in Social Stratification and Mobility, 8, 3-84.

$\rightarrow$ Ganzeboom, H. B. G., Treiman, D. J. \& Ultee, W. C. 1991. Comparative Intergenerational Stratification Research: Three Generations and Beyond. Annual Review of Sociology, 17, 277-302.

Goldthorpe, J. H. 1994. Class and Politics in Advanced Industrial Societies. Paper presented at the XVII World Congress of Sociology, Bielefeld, Germany.

Goldthorpe, J. H., Payne, C. \& Llewellyn, C. 1978. Trends in Class Mobility. Sociology, 12, 441-468.

Goodman, L. A. 1975. The Relationship Between Modified and Usual Multiple-regression Approaches to the Analysis of Dichotomous Variables. In D. R. Reise (ed.), Sociological Methodology 1976. pp. 83-110. San Francisco: Jossey-Bass.

Gunther, R., Sani, G. \& Shabad, G. 1986. Spain after Franco: The Making of a Competitive Party System. Berkeley: University of California Press.

$\rightarrow$ Hauser, R. M. 1978. A Structural Model for the Mobility Table. Social Forces, 56, 919-953.

Heath, A., Curtice, J., Jowell, R., Evans, G., Field, J. \& Witherspoon, S. 1991. Understanding Political Change: The British Voter, 1964-1987. Oxford: Pergamon Press.

Heath, A., Evans, G. \& Payne, C. 1995. Modelling the Class/Party Relationship in Britain, 1964-92. Journal of the Royal Statistics (forthcoming).

Heath, A., Jowell, R. \& Curtice, J. 1985. How Britain Votes. Oxford: Pergamon Press.

Holmberg, S. 1991. Voters on the Loose: Trends in Swedish Voting Behaviour. Göteburg (unpublished paper).

Hout, M., Brooks, C. \& Manza, J. 1993. The Persistence of Classes in Post-Industrial Societies. International Sociology, 8, 259-277.

$\rightarrow$ Hout, M., Brooks, C. \& Manza, J. 1995. The Democratic Class Struggle in the United States, 1948-1992. American Sociological Review, 60, 805-828.

ILO (International Labour Office) 1969. International Standard Classification of Occupations (revised edition). Geneva: International Labour Office.

Inglehart, R. 1990. Culture Shift in Advanced Industrial Society. Princeton: Princeton University Press.

$\rightarrow$ Kelley, J. \& McAllister, I. 1985. Class and Party in Australia: Comparison with Britain and the USA. British Journal of Sociology, 36, 383-420.

Kemp, D. A. 1978. Society and Electoral Behaviour in Australia: A Study of Three Decades. Brisbane: University of Queensland Press.

Kerr, H. H. 1987. The Swiss Party System: Steadfast and Changing. In H. Daalder (ed.), Party Systems in Denmark, Austria, Switzerland, The Netherlands, and Belgium. pp. 107-192. London: Frances Pinter.

$\rightarrow$ Knoke, D. 1973. Integenerational Occupational Mobility and the 
Political Party Preferences of American Men. American Journal of Sociology, 78, 1448-1468.

Korpi, W. 1983. The Democratic Class Struggle. London: Routledge \& Kegan Paul.

$\rightarrow$ Kurz, K. \& Muller, W. 1987. Class Mobility in the Industrial World. Annual Review of Sociology, 13, 417-442.

Lane, J.-E. \& Ersson, S. O. 1991. Politics and Society in Western Europe (second edition). London: Sage.

Laver, M., Mair, P. \& Sinott, R. (eds.) 1987. How Ireland Voted: The Irish General Election, 1987. Dublin: Poolbeg.

Lenski, G. 1970. Human Societies: A Macrolevel Introduction to Sociology. New York: McGraw-Hill.

Lenski, G., Lenski, J. \& Nolan, P. 1991. Human Societies: An Introduction to Macrosociology (sixth edition). New York: McGrawHill.

Lijphart, A. 1968. The Politics of Accommodation. Berkeley: University of California Press.

Lijphart, A. 1971. Class Voting and Religious Voting in the European Democracies: A Preliminary Report. Acta Politica, 6, 158-171.

Lijphart, A. 1984. Democracies: Patterns of Majoritarian and Consensus Government in Twenty-One Countries. New Haven: Yale University Press.

Lipset, S. M. 1960. Political Man: The Social Bases of Politics. London: Heinemann.

Lipset, S. M. 1983. Political Man: The Social Bases of Politics (expanded and updated edition). London: Heinemann.

Lipset, S. M. \& Zetterberg, H. 1956. A Theory of Social Mobility. Transactions of the Third World Congress of Sociology, 3, 155-177.

Listhaug, O. 1989. Citizens, Parties and Norwegian Electoral Politics 1957-1985: An Empirical Study. Trondheim: Tapir.

Mackie, T. T. \& Rose, R. 1991. The International Almanac of Electoral History (fully revised third edition). London: Macmillan.

MacRae, D. 1967. Parliament, Parties, and Society in France, 1946-1958. New York: St. Martin's Press.

$\rightarrow$ Manza, J., Hout, M. \& Brooks, C. 1995. Class voting in Capitalist Democracies Since WWII. Annual Review of Sociology, 21, 137-63.

Matheson, D. K. 1979. Ideology, Political Action and Finnish Working Class: A Survey Study of Political Behavior. Helsinki: Societas Scientiarum Fennica.

McAllister, I. \& Kelley, J. 1982. Class, Ethnicity, and Voting Behaviour in Australia. Politics, 17, 96-107.

NORC (National Opinion Research Center) 1948. Opinion News Supplement.

Nieuwbeerta, P. 1995. The Democratic Class Struggle in Twenty Countries, 1945-1990. Amsterdam: Thesis Publishers.

Nieuwbeerta, P. 1996. Contextual Effects of Class Mobility on Voting Behaviour in 16 Western Countries: 1956-1990. Bulletin de Methodologie Sociologique, 51, 42-63.

Nieuwbeerta, P. \& Ganzeboom, H. B. G. 1996. International Social Mobility and Politics File: Documentation of a Dataset of National Surveys Held in Sixteen Countries, 1956-1990. Amsterdam: Steinmetz Archive.

Nieuwbeerta, P. \& Ultee, W. C. 1993. Review of M. N. Franklin, T. T. 
Mackie, H. Valen et al. 1992. Electoral Change: Responses to Evolving Social and Attitudinal Structures in Western Countries. Acta Politica, 28, 88-91.

Przeworski, A. \& Spraque, J. 1986. Paper Stones: A History of Electoral Socialism. Chicago: University of Chicago Press.

$\rightarrow$ Raftery, A. 1986. Choosing Models for Cross-Classifications: Comment on Grusky and Hauser. American Sociological Review, 51, 145-146.

Ringdal, K. \& Hines, K. 1995. Patterns in Class Voting in Norway 1957-1989: Decline or 'Trendless Fluctuations'? Acta Sociologica, $38,33-51$.

Rose, R. (ed.) 1974. Electoral Behavior: A Comparative Handbook. New York: Free Press.

Rose, R. (ed.) 1980. Electoral Participation: A Comparative Analysis. Beverly Hills: Sage.

Rose, R. \& McAllister, I. 1986. Voters Begin to Choose: From ClosedClass to Open Elections in Britain. London: Sage.

Rose, R. \& Urwin, D. 1969. Social Cohesion, Political Parties and Strains in Regimes. Comparative Political Studies, 2, 7-67.

Sainsbury, D. 1987. Class Voting and Left Voting in Scandinavia: The Impact of Different Operationalizations of the Working Class. European Journal of Political Research, 15, 507-526.

Sainsbury, D. 1990. Party Strategies and the Electoral Trade-Off of Class-based Parties. European Journal of Political Research, 18, 29-50.

Siegfried, A. 1913. Tableau politique de la France de l'ouest sous la Troisieme Republique. Paris: Colin.

Sombart, W. 1976 [1906]. Why is There No Socialism in the United States? New York: M. E. Sharpe.

Sorokin, P. A. 1959 [1927]. Social and Cultural Mobility. New York: Free Press.

Stephens, J. D. 1981. The Changing Swedish Electorate: Class Voting, Contextual Effects, and Voter Volatility. Comparative Political Studies, 14, 163-204.

Svalastoga, K. 1979 [1959]. Prestige, Class, and Mobility. New York: Arno Press.

Thomsen, S. R. 1987. Danish Elections 1920-79: A Logit Approach to Ecological Analysis and Inference. Aarhus: Politica.

Tingsten, H. 1937. Political Behavior: Studies in Election Statistics. London: King \& Son.

Ultee, W. 1993. Jusqu'aux troisième et quatrième générations: Questions et techniques nouvelles dans les recherches en stratification et mobilité sociales. Recherches Sociologiques, 3, 5-22.

Valen, H. \& Katz, D. 1967. Poitical Parties in Norway. Oslo: Universitetsforlaget.

Von Beyme, K. 1985. Political Parties in Western Democracies. New York: St. Martin's Press.

Weakliem, D. L. 1989. Class and Party in Britain, 1964-1983. Sociology, 23, 285-297.

Weakliem, D. L. \& Heath, A. F. 1994. The Secret Life of Class Voting: Britain, France, and the United States Since the 1930s. Paper presented at the XVII World Congress of Sociology, Bielefeld, Germany. 
$\rightarrow$ Xie, Y. 1992. The Log-Multiplicative Layer Effect Model for Comparing Mobility Tables. American Sociological Review, 57, 380-395.

\section{Data References}

DDA:081

ESRC: 1577

ESRC:1987

ICPSR:7004

ICPSR:7098

ICPSR:7108

ICPSR:7214

ICPSR:7215

ICPSR:7216

ICPSR:7235

ICPSR:7250

ICPSR:7256

ICPSR:7259

ICPSR:7261

ICPSR:7281

ICPSR:7282

ICPSR:7298

ICPSR:7342

ICPSR:7768

ICPSR:7777

ICPSR:7870

ICPSR:7953

ICPSR:8196

ICPSR:8409

ICPSR:8544

ICPSR:8909

ICPSR:8946

ICPSR:9205

ICPSR:9383
Allardt, E., Uusitalo, H., Scandinavian Welfare Survey, 1972.

Bernard, S., Delruelle S. et al. Belgian Citizen in the Political System, 1975.

Capdevielle, J., Dupoirier, E., Grunberg, G., Schweisguth, E. \& Ysmal, C. French National Election Study, 1978.

Butler, D. \& Stokes, D. E. Political Change in Britain, 1969-1970.

Klingemann, H.-D. \& Pappi, F. U., German Pre- and Post-Election Study, 1969.

Kaase, M., Schleth, U., Adrian, W., Berger, M. \& Wildenmann, R., German Election Study: August-September 1969.

Campbell, A., Converse, P. et al. American National Election Study, 1956.

Campbell, A., Converse, P. et al. American National Election Study, 1958.

Campbell, A., Converse, P. et al. American National Election Study, 1960.

SRC (Survey Research Center), American National Election Study, 1964.

Butler, D. \& Stokes, D. E., Political Change in Britain 1963-1970.

Valen, H. Norwegian Election Study, 1965.

SRC (Survey Research Center), American National Election Study, 1966.

Heunks, F. M., Jennings, M. K., Miller, W. E., Stouthard, P. C. \& Thomassen, J. Dutch Election Study, 1970-1973.

SRC (Survey Research Center), American National Election Study, 1968.

Aitkin, D., Kahan, M. \& Stokes, D. E. Australian National Political Attitudes, 1967.

CPS (Center for Political Studies), American National Election Study, 1970.

Kerr, H., Sidjanski, D. \& Schmidtchen, G. Swiss Voting Study, 1972.

Verba, S., Nie, N. H. \& Kim, J. O., Political Participation and Equality in Seven Nations, 1966-1971.

Barnes, S. H. \& Kaase, M. et al., Political Action: An Eight Nation Study, 1973-1976.

Crewe, I., Saerlvik, B. \& Alt, J. British Election Study: October 1974, Cross-section.

Barnes, S. H. Italian Mass Election Survey. 1968.

Crewe, I., Saerlvik, B. \& Robertson, D. British Election Study: May 1979, Cross-section.

Heath, A. F. Jowell, R. M. Curtice, J. K. \& Field, E. J. British Election Study: June 1983.

Lambert, R. D., Brown, S. D., Curtis, J. E., Kay, B. J. \& Wilson, J. M. Canadian National Election Study, 1984.

International Social Science Program (ISSP), International Social Science Program: Role of Government, 1985-1986.

Borre, O. et al. Danish Election Studies Continuity File, 1971-1981.

International Social Science Program (ISSP), International Social Science Program: Social Networks and Support Systems, 1986.

International Social Science Program (ISSP), International Social Science Program: Social Inequality, 1987. 
ICPSR:9505

NSD:NOR77e NSD:NOR81e NSD:NOR85e NSD:NOR89e NSD:NOR90e NYM:BRI87e NYM:ITA85

NYM:NET87

NYM:NET89

NYM:SWE90

SSDA:423

SSDA:445

SSDA:570

SSDA:7

SSDA:8

SSDA:9

STEIN:P0328

STEIN:P0350

STEIN:P0353

STEIN:P0354

STEIN:P0633

STEIN:P0653

STEIN:P0866

STEIN:P1012

STEIN:P1100

ZA:1188

ZA:1233

ZA:1700

ZA:1795

ZA:1800
Davis, J. A. \& Smith, T. W. General Social Survey Cumulative File, 1972-1991.

Valen, H. Norwegian Election Study, 1977.

Valen, H. Norwegian Election Study, 1981.

Valen, H. Norwegian Election Study, 1985.

Valen, H. Norwegian Election Study, 1989.

Valen, H. Norwegian Election Study, 1990.

Heath, A. F. et al. British Election Study: 1987.

Department of Social Policy, University of Trento, Department of Education Science, University of Bologna, and Department of Human Science, University of Trieste, Survey of Social Mobility and Education Italy, 1985.

Hermkens, P. L. J. \& van Wijngaarden, P. J. Criteria for Justification of Income Differences, Netherlands, 1987.

Arts, K., Hollander, E., Renckstorf, K. \& Verschuren, P. Mediaequipment, Media-exposure and Media-use in The Netherlands, 1989.

Svallfors, S. Attitudes to Inequality, 1990.

Kelley, J. L., Cushing, R. G. \& Headey, B. Australian National Social Science Survey, 1984.

McAllister, I. \& Mughan, A. Australian Election Survey, 1987.

McAllister, I., Jones, R., Papodalis, E. \& Gow, D. Australian Election Survey, 1990.

Broom, L., Jones, F. L. \& Zubrzycki, J. Social Stratification in Australia, 1965.

Broom, L., Duncan-Jones, P., Jones, F. L., McDonnel, P. \& Williams, T. Social Mobility in Australia Project, 1973.

Aitkin., MacQuarie University Australian Political Attitudes Survey, 1979.

Central Bureau voor Statistiek (CBS), Life Situation Survey, Netherlands, 1977.

Werkgroep National Kiezersonderzoek, Dutch Parliamentary Election Study, 1981.

Werkgroep National Kiezersonderzoek, Dutch Parliamentary Election Study, 1972.

Werkgroep National Kierzersonderzoek, Dutch Parliamentary Election Study, 1977.

Werkgroep National Kiezersonderzoek, Dutch Parliamentary Election Study, 1982.

Hermkens, P. L. J. \& van Wijngaarden, P. J. Criteria for Justification of Income Differences, Netherlands, 1976.

Van der Eijk, C., Irwin, G. A. \& Niemoeller, B. Dutch Parliamentary Elections Study, 1986.

Felling, A. J. A., Peters, J. \& Schreuder, O. Social Relevance of Religion in The Netherlands, 1985.

Felling, A., Peters, J. \& Schreuder, O. Social Relevance of Religion in The Netherlands, 1990.

Allerbeck, K. R., Kaase, M., Klingemann, H. D., Stouthard, Ph.C., Heunks, F. J., Thomassen, J. J. A., van Deth, J. W., Barnes, S. H., Farah, B. G., Inglehart, R. \& Jennings, M. K. Political Action II, 1979-1980.

ZUMA (Zentrum fuer Umfragen, Methoden, und Analysen, ZUMAStandard Demographie (Zeitreihe), Germany, 1976-1980.

International Social Science Program (ISSP), International Social Science Program: Family and Changing Sex Roles, 1988.

Allerbeck, K. R., Lepsius, M. R., Mayer, K. U., Müller, W., Opp, K. D., Pappi, F. U., Schreuch, E. K. \& Ziegler, R. Allgemeine Bevolkerungsmufrage der Sozial-wissenschaften Allbus Kumulierter Datensatz, 1980-1988.

ZUMA (Zentrum fuer Umfragen, Methoden, und Analysen, German 
ZA: 1840

ZA:1950
Social Survey (Allbus), 1990.

International Social Science Program (ISSP), International Social Science Program: Work Orientations, 1989.

International Social Science Program (ISSP), International Social Science Program: Role of Government II, 1990.

\section{Data Archives}

\section{DDA \\ ESRC \\ ICPSR \\ NSD \\ NYM \\ SSDA \\ STEIN \\ ZA}

\author{
Danish Data Archive, Odense, Denmark. \\ ESRC Data Archive, Essex, United Kingdom. \\ Inter-University Consortium for Political and Social Research, Ann \\ Arbor (MI), USA. \\ Norwegian Social Science Data Service, Bergen, Norway. \\ Department of Sociology, University of Nijmegen, Nijmegen, The \\ Netherlands. \\ Social Science Data Archive, Canberra, Australia. \\ Steinmetz Archive, Amsterdam, The Netherlands. \\ Zentral Archive, Köln, Germany.
}

\section{Appendix A: Aggregated Country Data}

The aggregated country data analysed in this article, i.e. 324 tables crossclassifying class (manual/non-manual) by party voted for (left-wing/rightwing) from 20 countries in the period 1945-90, were collected from two types of sources: tables published in various articles and books, and tables calculated with the individual level data presented in Appendix B. The tables published in articles and books come from the following sources: Australia: Alford (1963); Baxter et al. (1991); McAllister (pers. comm. 1992); Rose (1974). Austria: Rose \& Urwin (1969); Crewe \& Denver (1985); Lijphart (1971); Lane \& Ersson (1991). Belgium: Frognier (1975); Lijphart (1971); Rose (1980). Britain: Alford (1963); Heath et al. (1985, 1991); NORC (1948); Rose \& McAllister (1986). Canada: Alford (1963); Rose (1974); Rose (1980). Denmark: Andersen (1984); Lane \& Ersson (1991); Rose (1980); Sainsbury (1990). Finland: Allardt \& Littunen (1964); Allardt \& Wesolowski (1978); Berglund (1988); Matheson (1979); Rose \& Urwin (1969); Rose (1974). France: Converse \& Pierce (1986); Dalton (1988); Dalton et al. (1984); MacRae (1967). Germany: Dalton (1988); Forschungsgruppe Wahlen (1990); De Jong (1956); Lijphart (1971); Rose \& Urwin (1969). Ireland: Crewe \& Denver (1985); Laver et al. (1987); Rose (1974). Italy: Allum (1979); Crewe \& Denver (1985); Lijphart (1971); Lipset (1983); Rose (1974); Von Beyme (1985); Rose \& Urwin (1969). The Netherlands: Lijphart (1968). Norway: Listhaug (1989); Valen (pers. comm. 1992). Portugal: Lane \& Ersson (1991). Spain: Gunther et al. (1986); Rose (1980). Sweden: Holmberg (1991); Stephens (1981). Switzerland: Kerr (1987); Lane \& Ersson (1991); Rose (1980). United States: Alford (1963); Abramson et al. (1990).

\section{Appendix B: Individual Level Data}

The individual level data analysed come from a collection of 113 national representative surveys from 16 countries in the period 1956-90. These data sets have been extracted, made comparable, and collected in one large 
combine file, the 'International Stratification, Mobility and Politics File'. For detailed information on this file, we refer to the accompanying codebook (Nieuwbeerta \& Ganzeboom 1996). In this appendix we confine ourselves by giving references to the original files. The names of the files are acronyms: the first three letters represent the country, the two figures the year the survey took place. The reference numbers indicate the numbers in the catalogues of the data archives where the files were stored and to the reference list of this article.

\begin{tabular}{|c|c|c|c|}
\hline File & Reference & File & Reference \\
\hline AUS65 & SSDA:7 & GER69e & ICPSR:7108 \\
\hline AUS67 & ICPSR:7282 & GER69f & ICPSR:7098 \\
\hline AUS73 & SSDA:9 & GER75p & ICPSR:7777 \\
\hline AUS79 & SSDA:9 & GER76z & ZA:1233 \\
\hline AUS84 & SSDA:423 & GER77z & ZA:1233 \\
\hline AUS85i & ICPSR:8909 & GER78c & $\mathrm{ZA}: 1233$ \\
\hline AUS86i & ICPSR:9205 & GER78 $x$ & ZA:1233 \\
\hline AUS87e & SSDA:445 & GER79x & $\mathrm{ZA}: 1233$ \\
\hline AUS87i & ICPSR:9383 & GER79z & ZA:1233 \\
\hline AUS90e & SSDA:570 & $\begin{array}{l}\text { GER80a } \\
\text { GER80c }\end{array}$ & $\begin{array}{l}\text { ZA:1795 } \\
\text { ZA:1233 }\end{array}$ \\
\hline AUT74p & ICPSR:7777 & GER80p & $\mathrm{ZA}: 1188$ \\
\hline AUT85i & ICPSR:8909 & GER80z & ZA:1233 \\
\hline AUT88i & ZA:1700 & GER82a & ZA:1795 \\
\hline AUT89i & ZA: 1840 & $\begin{array}{l}\text { GER84a } \\
\text { GER86a }\end{array}$ & $\begin{array}{l}\text { ZA:1795 } \\
\text { ZA:1795 }\end{array}$ \\
\hline BEL75 & ESRC:1577 & $\begin{array}{l}\text { GER87i } \\
\text { GER88a }\end{array}$ & $\begin{array}{l}\text { ICPSR:9383 } \\
\text { ZA:1795 }\end{array}$ \\
\hline $\begin{array}{l}\text { BRI64e } \\
\text { BRI66e }\end{array}$ & $\begin{array}{l}\text { ICPSR:7250 } \\
\text { ICPSR:7250 }\end{array}$ & GER90a & ZA:1800 \\
\hline BRI70e & ICPSR:7004 & IRE89i & ZA:1840 \\
\hline $\begin{array}{l}\text { BRI74e } \\
\text { BRI79e }\end{array}$ & $\begin{array}{l}\text { ICPSR:7870 } \\
\text { ICPSR:8196 }\end{array}$ & IRE90i & $\mathrm{ZA}: 1950$ \\
\hline BRI83e & ICPSR:8409 & ITA68e & ICPSR:7953 \\
\hline BRI85i & ICPSR:8909 & ITA75p & ICPSR: 7777 \\
\hline $\begin{array}{l}\text { BRI86i } \\
\text { BRI87e }\end{array}$ & $\begin{array}{l}\text { ICPSR:9205 } \\
\text { NYM.ENG87e }\end{array}$ & ITA85 & NYM:ITA85 \\
\hline BRI87i & ICPSR:9383 & & \\
\hline BRI88i & $\mathrm{ZA}: 1700$ & NET70 & ICPSR:7261 \\
\hline BRI89i & $\mathrm{ZA}: 1840$ & NET71 & ICPSR:7768 \\
\hline BRI90i & $\mathrm{ZA}: 1950$ & $\begin{array}{l}\text { NET72e } \\
\text { NET74p }\end{array}$ & $\begin{array}{l}\text { STEIN:P0353 } \\
\text { ICPSR:7777 }\end{array}$ \\
\hline CAN84e & ICPSR:8544 & $\begin{array}{l}\text { NET76 } \\
\text { NET77e }\end{array}$ & $\begin{array}{l}\text { STEIN:P0653 } \\
\text { STEIN:P0354 }\end{array}$ \\
\hline DEN71e & ICPSR:8946 & NET771 & STEIN:P0328 \\
\hline DEN72s & DDA:081 & NET79p & ZA:1188 \\
\hline DEN75e & ICPSR:8946 & NET81e & STEIN:P0350 \\
\hline DEN77e & ICPSR:8946 & NET82e & STEIN:P0633 \\
\hline DEN79e & ICPSR:8946 & NET85s & STEIN:P1012 \\
\hline DEN81e & ICPSR:8946 & $\begin{array}{l}\text { NET86e } \\
\text { NET87 }\end{array}$ & $\begin{array}{l}\text { STEIN:P0866 } \\
\text { NYM:NET87 }\end{array}$ \\
\hline FIN72s & DDA:081 & $\begin{array}{l}\text { NET89m } \\
\text { NET90s }\end{array}$ & $\begin{array}{l}\text { NYM:NET89m } \\
\text { STEIN:P1100 }\end{array}$ \\
\hline FIN75p & ICPSR:777 & & \\
\hline FRA78e & ESRC:1987 & NOR65e & ICPSR:7256 \\
\hline
\end{tabular}




$\begin{array}{llll}\text { File } & \text { Reference } & \text { File } & \text { Reference } \\ \text { NOR72s } & \text { DDA:081 } & \text { USA72g } & \text { ICPSR:9505 } \\ \text { NOR77e } & \text { NSD:NOR77e } & \text { USA73g } & \text { ICPSR:9505 } \\ \text { NOR81e } & \text { NSD:NOR81e } & \text { USA74g } & \text { ICPSR:9505 } \\ \text { NOR85e } & \text { NSD:NOR85e } & \text { USA74p } & \text { ICPSR:7777 } \\ \text { NOR89e } & \text { NSD:NOR89e } & \text { USA75g } & \text { ICPSR:9505 } \\ \text { NOR90e } & \text { NSD:NOR90e } & \text { USA76g } & \text { ICPSR:9505 } \\ & & \text { USA77g } & \text { ICPSR:9505 } \\ \text { SWE72s } & \text { DDA:081 } & \text { USA78g } & \text { ICPSR: }: 9505 \\ \text { SWE90 } & \text { NYM:SWE90 } & \text { USA80g } & \text { ICPSR:9505 } \\ & & \text { USA82g } & \text { ICPSR: }: 9505 \\ \text { SWI72 } & \text { ICPSR:7342 } & \text { USA83g } & \text { ICPSR: }: 905 \\ \text { SWI76p } & \text { ICPSR:7777 } & \text { USA84g } & \text { ICPSR: }: 505 \\ \text { USA56e } & \text { ICPSR:7214 } & \text { USA86g } & \text { ICPSR:9505 } \\ \text { USA58e } & \text { ICPSR:7215 } & \text { USA85g } & \text { ICPSR:9505 } \\ \text { USA60e } & \text { ICPSR:7216 } & \text { USA87g } & \text { ICPSR:9505 } \\ \text { USA64e } & \text { ICPSR:7235 } & \text { USA88g } & \text { ICPSR:9505 } \\ \text { USA66e } & \text { ICPSR:7259 } & \text { USA89g } & \text { ICPSR:9505 } \\ \text { USA68e } & \text { ICPSR:7281 } & \text { USA90g } & \text { ICPSR:9505 } \\ \text { USA70e } & \text { ICPSR:7298 } & & \\ \text { ISA } & & & \end{array}$




\section{Appendix C: Left-wing Political Parties}

Australia:

Austria:

Belgium:

Britain:

Canada:

Denmark:

Finland:

France:

Germany:

Greece:

Ireland:

Italy:

Luxembourg:

The Netherlands:

Norway:

Portugal:

Spain:

Sweden:

Switzerland:

United States:
Australian Labour Party (0101); Communist Party (0110); Democratic Labour Party (0121); Queensland Labour Party (0122);

Socialists (0201); Communist Party (0205); Democratic Progressive Party (0212);

Belgian Socialist Party (0303); Communist Party (0310); Walloon Workers' Party (0317); Labour Party (0324); Flemish Socialist Party (0330);

Labour Party (2406); Communist Party (2410); Social Democratic and Labour Party (2418); Social Democratic Party (2420);

Communist Party - Labour Progressive Party (0406); New Democratic Party (0408);

Social Democrats (0504); Communist Party (0509); Socialist People's Party (0516); Left Socialist Party (0518);

Social Democrats (0601); Finnish People's Democratic Union (0613); Social Democratic League of Workers and Smallholders (0615); Democratic Alternative (0622);

Socialist Party (0701); Communist Party (0709); Other Extreme left (0718); Unified Socialist Party (0719); Other Left (0727);

Social Democrats (0802); Communist Party (0828); Action for Democratic Progress (0850);

Communist Party of Greece (0904); United Democratic Left (0925); Communist Party of Greece (0935); Pan-Hellenic Socialist Movement (0937); Greek Left (0945);

Irish Labour Party (1108); Communists (1109); National Progressive Democrats (1118); Workers' Party (1119); Socialist Labour Party (1121); Democratic Socialist Party (1123);

Socialist Party (1303); Communist Party (1311); Social Democrats (1323); United Socialist Party (1331); Manifesto/Party of Proletarian Unity for Communism (1332); Proletarian Democracy (1337);

Social Democratic Party (1502); Communist Party (1507); Social Democratic Party (1519); Independent Socialists (1521);

Communist Party (1710); Labour Party (1723); Pacifist Socialist Party (1727); Democratic Socialists '70 (1730);

Labour Party (1904); Communist Party (1909); Socialist People's Party (1914);

Communist Party (2002); Socialist Party (2004); Democratic Movement (2005); Movement of the Socialist Left (2006); Popular Democratic Union (2007); Revolutionary Socialist Party (2012); Union of the Socialist and Democratic Left (2013); Socialist Unity Party (2015);

Socialist Party (2101); Communist Party (2102); Popular Socialist Party (2132); Spanish Labour Party (2133);

Social Democrats (2205); Communist Party (2210);

Social Democrats (2305); Communist Party (2309); Autonomous Socialist Party (2317);

Democratic Party (2501); Socialist Labor Party (2515); Socialist Party (2517); Communist Party (2521).

The numbers in parentheses refer to the numbers of the chapters and parties in Mackie \& Rose (1991). 